\title{
MODERN BLAST FURNACE IRONMAKING TECHNOLOGY: POTENTIALS TO MEET THE DEMAND OF HIGH HOT METAL PRODUCTION AND LOWER ENERGY CONSUMPTION
}

\author{
E.A. Mousa ${ }^{1,2 *}$ \\ ${ }^{1}$ Researcher Scientist at Process Metallurgy Department, Swerim AB, \\ SE-971 25 Luleå, Box 812 Sweden. \\ ${ }^{2}$ Associated Professor at Central Metallurgical Research and Development Institute \\ (CMRDI), Helwan, P.O. Box 87 Egypt.
}

Received 04.04.2019

Accepted 20.06.2019

\begin{abstract}
Iron and steel making is one of the most intense energy consuming in the industrial sectors. The intensive utilization of fossil carbon in the ironmaking blast furnace (BF) is related directly to $\mathrm{CO}_{2}$ emission and global warming. Lowering the energy consumption and $\mathrm{CO}_{2}$ emission from $\mathrm{BF}$ comes on the top priorities from both economic and environmental aspects. The $\mathrm{BF}$ has undergone tremendous modifications and development to increase production and improve the overall efficiency. Both technological development and scientific research drive one another to reach optimum operation conditions, which are very close to the ideal conditions; however, further development is still required to meet the stringent environmental regulations. The present article provides a comprehensive review of recent research and development which were carried out in modern blast furnace to increase the productivity meanwhile reduce the energy consumption and $\mathrm{CO}_{2}$ emission to meet the demand of steel market and the environmental protection. The recent technological and metallurgical improvements in the BF are intensively discussed including: (i) modifications of BF design, top charging and measuring system, (ii) upgrading of conventional top charging burden and alternative agglomerates, (iii) developing of tuyeres injection system and injected materials, and (iv) potentials of waste heat recovery and usage. These topics are reviewed and discussed in some details to elucidate the potential of recent progress in BF technology in saving the energy consumption and lowering $\mathrm{CO}_{2}$ emission. In this paper, the major research and development which have been carried out in ironmaking BF technology are reviewed with an overview of the future prospects.
\end{abstract}

Keywords: blast furnace; $\mathrm{CO}_{2}$ emission; energy saving; top charging; tuyeres injection; waste heat recovery.

\footnotetext{
*Corresponding author: Elsayed Mousa,mousa71@yahoo.com
} 


\section{Contents}

$\begin{array}{ll}\text { 1. Introduction } & 71\end{array}$

2. Development in BF Design and Measuring Systems 72

3. Development in Top Charging Materials 75

3.1 Active Nut Coke 76

3.2 Cold Bonded Briquettes and Pre-reduced Agglomerates 77

3.3 Renewable Biomass $\quad 79$

4. Development in Tuyeres Injections 81

4.1 Pulverized Coal Injection (PCI) 81

4.2 Oil and Natural Gas Injection 85

4.3 Off-Gases Injection 86

4.4 Waste Plastics and Biomass Injection 88

5. Potentials of Waste Heat Recovery (WHR) 89

5.1 Analysis of Waste Heat in Steel Plant 89

5.2 Benefits and Challenges of WHR 90

5.3 WHR from BF Slag 92

Acknowledgment 98

References $\quad 98$ 


\section{Introduction}

The steel industry is considered as a pillar of the economy in many of advance and development countries. It is one of the most important sectors which have a high impact on global economic growth. More than 6.0 million people around the world work for this vital sector, with an estimated turn offer of 900 billion USD per year [1]. In recent years, steel production has sharply increased to reach about 1.7 billion tons in 2017 [2]. Moreover, steel production and usage are expected to increase to reach 2.8 billion tons to meet the future needs of a growing population in 2050 [3]. On the other hand, steel manufacturing is one of the most significant energy- and carbon- consuming sectors. The global energy consumption in steelmaking is estimated to be about $20 \%$ of the annual industrial energy requirements. The fossil carbon is the primary source of heat and reducing agents in iron and steel making and consequently represents a major contribution to the global anthropogenic $\mathrm{CO}_{2}$ emission. According to the International Energy Agency, the iron and steel industry accounts for approximately 7-9\% of total world $\mathrm{CO}_{2}$ emissions [4]. The $\mathrm{CO}_{2}$ emission from iron and steelmaking reached to about 2.3 billion tons in 2007 and it is expected to reach more than 3.0 billion tons in 2050 [3]. Tackling $\mathrm{CO}_{2}$ emission is one of the most critical tasks facing the world today because further pollutions and emissions will threaten our health, communities, economy, and international security. Nowadays, the reduction of specific energy consumption and $\mathrm{CO}_{2}$ emission are coming on the top priorities of iron and steelmaking due to the dynamic growth of energy prices as well as the commitment of governments to decrease $\mathrm{CO}_{2}$ emissions according to Paris agreement which entered into force on 4 November 2016 [5, 6]. Several ambitious actions were set all over the world to combat carbon footprint. In Europe, for instance, 20-20-20 target aims at 20\% decrease in greenhouse gas emissions compared to 1990 levels, $20 \%$ share of renewable energy and $20 \%$ reduction of primary energy consumption by 2020 [7]. Besides, $\mathrm{CO}_{2}$ Breakthrough Program was launched by the American steel industry aims to dramatically reduce $\mathrm{CO}_{2}$ emission from iron and steelmaking processes [8].

Although the steel industry is energy and carbon-intensive, it is essential to mention that steel industry represents the core of green economy as the sectors and technologies which drive the green economy such as wind energy, low-carbon transport, clean energy and light vehicles, fuel-efficient infrastructure and recycling facilities are all dependent on steel products. Furthermore, steel is the most recycled material in the world; with over $650 \mathrm{Mt}$ (million ton) recycled annually and over $97 \%$ of the raw materials used for steelmaking were converted to steel products and by-products [1]. Once the steel is produced it becomes a permanent resource for society as long as it is recovered at the end of each product life cycle [9]. The combination of strength, recyclability, availability, versatility, and affordability makes the steel as a unique material for many applications. The steel industry has recently undergone tremendous modification to reduce energy consumption and $\mathrm{CO}_{2}$ emission, but further decreasing is still required. The ironmaking process is the highest $\mathrm{CO}_{2}$ emission part in steel production route due to the intensive utilization of fossil fuels for heating, melting, and reduction of iron ores. The most common ironmaking process used worldwide is the $\mathrm{BF}$ which produces nowadays about $70 \%$ of total world steel production. Although many alternative ironmaking technologies were developed, the BF is still the most cost-effective and highly productive process for hot metal and probably remains so for the next decades. 
This article gives insights on the major modifications which have been done in ironmaking BF in terms of technical and scientific aspects. The recent development in the $\mathrm{BF}$ technology and its potentials in lowering the energy consumption and $\mathrm{CO}_{2}$ emission will be thoroughly discussed and the research gaps will be filled by providing thoughts and recommendation that contribute in solving the challenges. The discussion will focus on the development in BF design and measuring systems, developing top charging materials, the progress of tuyeres injection and the recent potentials in waste heat recovery from BF slag. This article gives insights on the major modifications which have been done in BF in terms of scientific and technical aspects.

\section{Development in BF Design and Measuring Systems}

The BF was created in a long way of experiences through which tremendous modifications and improvements were conducted to reach the current status. Intensive work was done to increase BF productivity in order to meet the high demand for steel. The working volume of the $\mathrm{BF}$ has increased from less than $100 \mathrm{~m}^{3}$ to more than 5000 $\mathrm{m}^{3}$ [10]. The largest BFs at present are about $80 \mathrm{~m}$ in total height, with an inner height of about 33-34 $\mathrm{m}$ and a maximum internal diameter of about $16-17 \mathrm{~m}$ and have an internal volume of about $4500-5500 \mathrm{~m}^{3}$. A furnace of this size produces approximately 10,000 13,000 tons of hot metal a day with annual production more than 4.0 Mt. In 2016 POSCO Steelworks in South Korea has started hot metal production form the world`s largest BF with an internal volume $\sim 6000 \mathrm{~m}^{3}$ and annual production of about $5.65 \mathrm{Mt}[10,11]$. It was reported that BFs with an internal volume in the range of $3000-5000 \mathrm{~m}^{3}$ seems optimal for BF-performance [12-16]. This means the BF-performance is more correlated to specific productivity which measures the efficiency in terms of ton hot metal $(\mathrm{tHM}) / \mathrm{m}^{2} /$ day [17]. The highest specific productivity corresponds to the working volume of about $2700-3700 \mathrm{~m}^{3}$ with maximum specific productivity $\sim 2.5 \mathrm{t} / \mathrm{m}^{3} / \mathrm{d}$. The minimum coke rate corresponds to the working volume of about $3000-3800 \mathrm{~m}^{3}$. The minimum coke consumption rate is around $330 \mathrm{~kg} / \mathrm{tHM}$ and the average is around $363 \mathrm{~kg} / \mathrm{tHM}$ [13].

The furnace size accounts for only $50 \%$ of BF improvements in productivity while many other parameters are responsible for increasing productivity as can be seen in Fig. 1 [18]. Developing of charged burden, furnace design, injection technologies, and process control helps in the reduction of coke consumption. For instance, the BF charging system was developed to sustain a good distribution of feeding materials inside the furnace and consequently improve the gas streaming and production rate. The introduction of a bellless top charging system in the early 1970s instead of the two-bell system was a milestone for modern charging system of BF. This system allows easier burden distribution through a rotating chute and consequently uniform distribution of voidage and particle size of charged materials inside the furnace. 


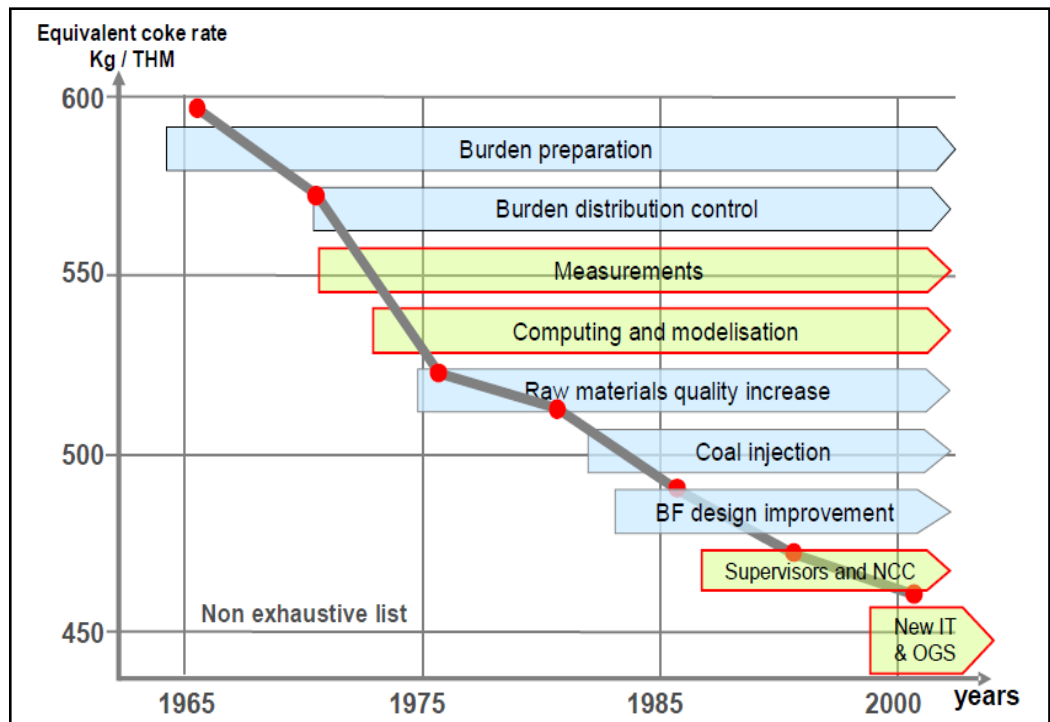

Fig. 1. Advances in the blast furnace to reduce the coke consumption [18].

Parallel with the development of the top charging system, the hot stoves system at the lower part of the shaft has undergone tremendous modification as can be seen in Fig. 2 [19]. About $1400 \mathrm{~m}^{3} / \mathrm{tHM}$ hot blast is blown into the modern BF at the temperature of $1100-1200{ }^{\circ} \mathrm{C}$. The hot blast reacts with coke and pulverized coal in the BF raceway to generate reducing gases $\left(\mathrm{CO}\right.$ and $\left.\mathrm{H}_{2}\right)$ meanwhile increasing the raceway adiabatic flame temperature (RAFT) to $\sim 2100-2300{ }^{\circ} \mathrm{C}$.

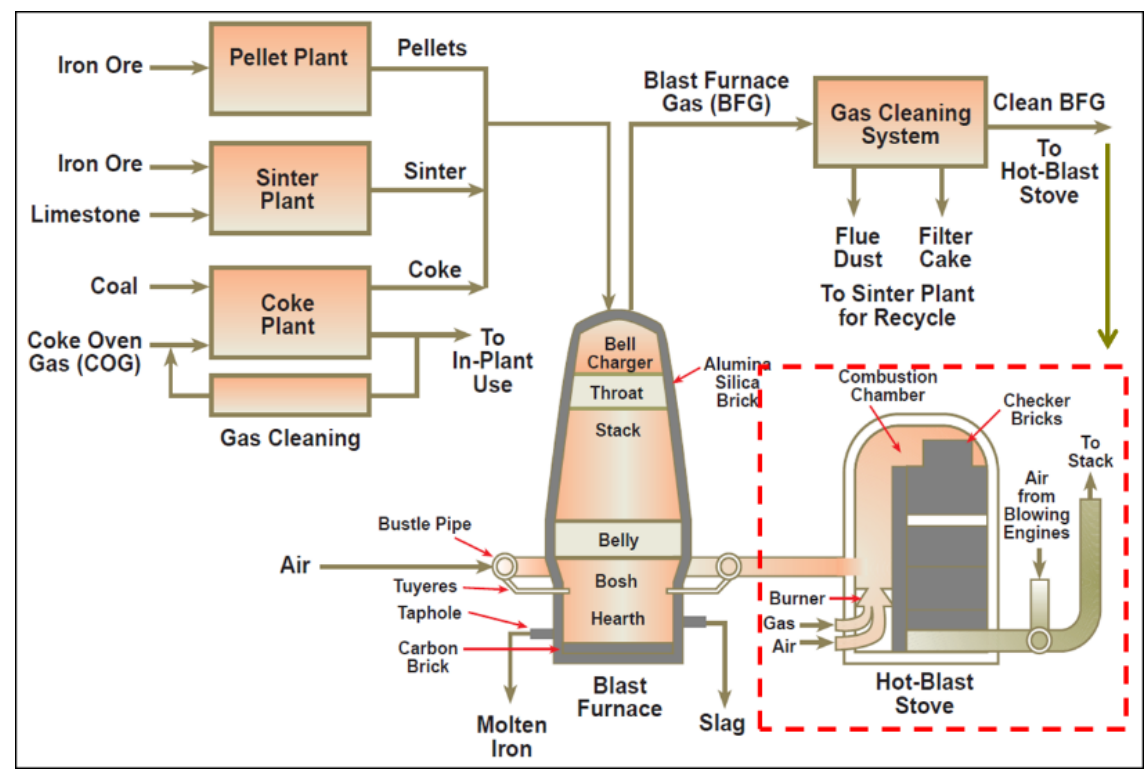

Fig. 2. Schematic diagram of blast furnace and auxiliary hot blast stoves [19]. 
Preparation of hot blast begins by heating the stoves using gas fuel mixture of coke oven gas (COG), natural gas (NG) and BF gas (BFG) [20-22]. The hot stove consists of two parts work as combustion and heat exchanger for fuel gases and hot blast. The hot blast can be enriched with oxygen to improve the combustion efficiency at the BF raceway. Moreover, the enrichment of combustion air with oxygen reduces the nitrogen content and consequently increases the RAFT. As oxygen enrichment increases, the coke consumption in BF decreases as can be seen in Fig. 3 [21]. Therefore, as the blast temperature and oxygen enrichment increase, the BF efficiency increases, meanwhile the coke consumption and $\mathrm{CO}_{2}$ emission decrease.

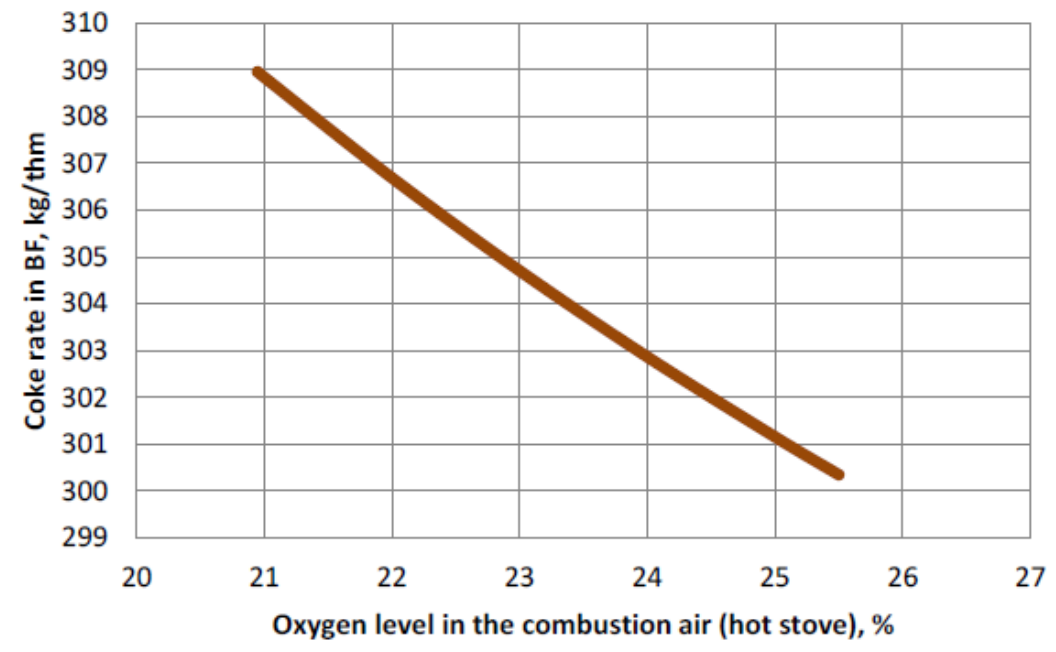

Fig. 3. Correlation between oxygen level in the blast and coke rate [21].

Besides the development of the upper and lower part of BF, the measuring systems were significantly modified. In the past, the BF was considered as "black box" due to the less available information on the inner status and inner phenomena. During the last 30 years, many studies and experimental work based on sophisticated measuring devices and techniques, as can be seen in Fig. 4, were developed and helped the ironmakers to understand many of complex inner phenomena and to work on improving the furnace efficiency [23]. 


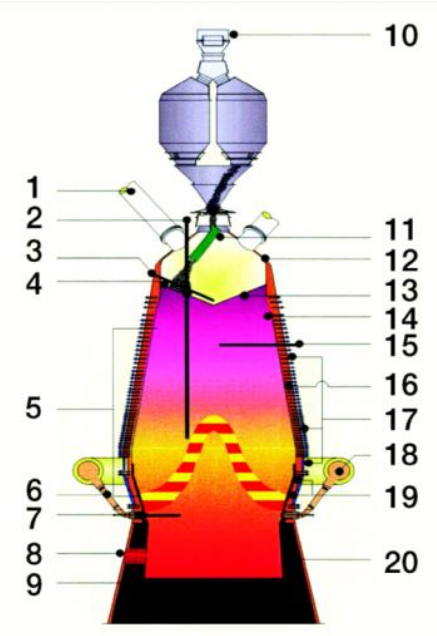

1 Top-gas analysis

2 Vertical probe

3 Top-gas temperature distribution and gas analysis

4 Peripheral temperature distribution and gas analysis

5 Shaft pressure distribution; wall gas analysis

6 Blast volume at tuyere

7 Tuyere probe

8 Tapping data of hot metal, slag, analysis, temperature

9 Bottom temperature

10 Burden weight, analysis, size segregation

11 Burden distribution

12 Infra-red temperature distribution

13 Descent behaviour

14 Descent velocity

15 Horizontal probe

16 Refractory temperature (hearth up to stockline)

17 Heat flow to cooling system

18 Blast data: volume, pressure, analysis, temperature

19 Stave temperature

20 Sensor for hearth liquid level control

Fig. 4. Development in blast furnace measuring systems [21].

Recently measuring devices (vertical probe and tuyeres probe) were designed to assist the development of BF modeling. The vertical probe gives feedback on the gas temperature and gas composition from the charging level to the cohesive zone. On the other hand, the tuyeres probe gives feedback on gas distribution in the raceway zone. Utilization of such sophisticated devices and measuring units has provided a clear vision of the inner status of BF. Consequently, further R \& D were conducted to improve the BF-performance. Some developments were able to reach a full scale implementation (such as pulverized coal injection, charging nut coke, and cold-bond briquettes) in modern BF while others (such as self-reduced agglomerates, biomass for top charging and injection, top gas recycling, recycling of dust and sludge, and minimizing dust emissions) are still under investigation in pilot and lab scale. Also, specific attention is being paid nowadays on the recovery of waste heat in the integrated steel plant using waste heat recovery unit. These themes will be discussed in detail in the next sections.

\section{Development in Top Charging Materials}

As indicated in the previous section, the BF in old design was quite small, and it was mainly based on top charging lump iron ores and charcoal. Later, in large and modern $\mathrm{BF}$, charcoal and lump ores were replaced by more efficient coke, sinter, and pellets. Modern BFs favor high strength coke and high iron content sinter and pellets. The highquality coke, sinter, and pellets increased BF efficiency and productivity. Even with these improvements, the economic and environmental restrictions represented in high energy cost and fossil $\mathrm{CO}_{2}$ emission have enforced the ironmakers to continue further developments on top charging materials. 


\section{Active Nut Coke}

Modern BF requires large coke size $(40-60 \mathrm{~mm}$ or $40-80 \mathrm{~mm}$ ) with low reactivity to reduce the coke consumption in the upper part of $\mathrm{BF}$ shaft and to maintain good permeability in the lower part of the shaft [24]. Also, the size distribution should be narrow to maintain permeable coke structure in the BF [25]. The screening of metallurgical coke to get the proper size for BF resulted in a generation of under-sieve small coke namely "nut coke". Due to the relatively high price of coke in addition to pollutions emissions during its production, there are several attempts to exploit the undersieve coke or nut coke in the BF. The attempts were started by charging nut coke with different ratios $(5-30 \%)$ within the coke layers. This charging mode demonstrated a negative impact on BF productivity $(-0.9-6.5 \%)$ due to the non-uniform distribution and disturbance of ascending gases in the shaft [26]. Studies were conducted on charging nut coke within iron burden layers, as shown in Fig. 5 [26-34]. This charging mode demonstrated a positive impact on the iron burden permeability, reducibility, and reducing gas efficiency.

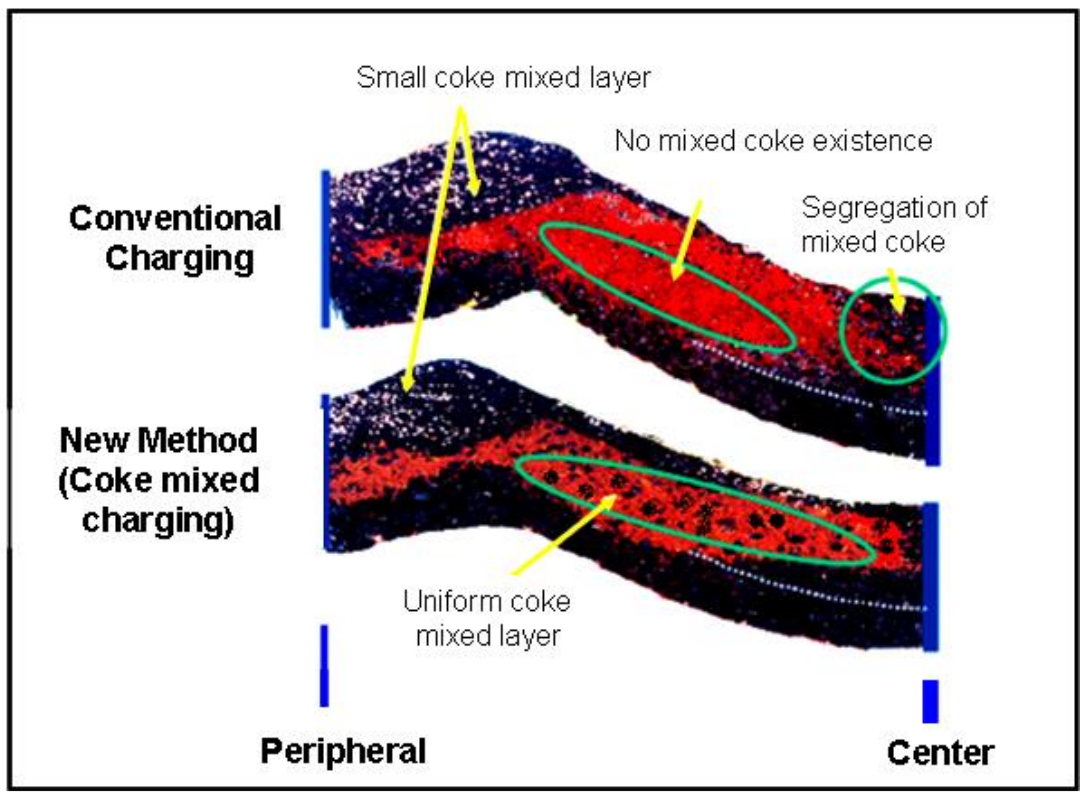

Fig. 5. Comparison between the conventional charging method and coke mixed charging method [35].

One of the critical issues that should be considered to get smooth operation is the uniform mixing of nut coke in the ore layer to maintain proper gas distribution and maintain the required permeability especially in the cohesive zone [26]. Mixing of nut coke within the ore bed is very effective in the enhancement of carbon solution loss reaction from active coke while protecting the large size coke from gasification and disintegration [35, 36]. This participates in lowering the temperature of the thermal reserve zone (TRZT) and consequently decreases the total coke consumption in the BF. Fig. 6 shows the relation between TRZT and coke rate consumption. 


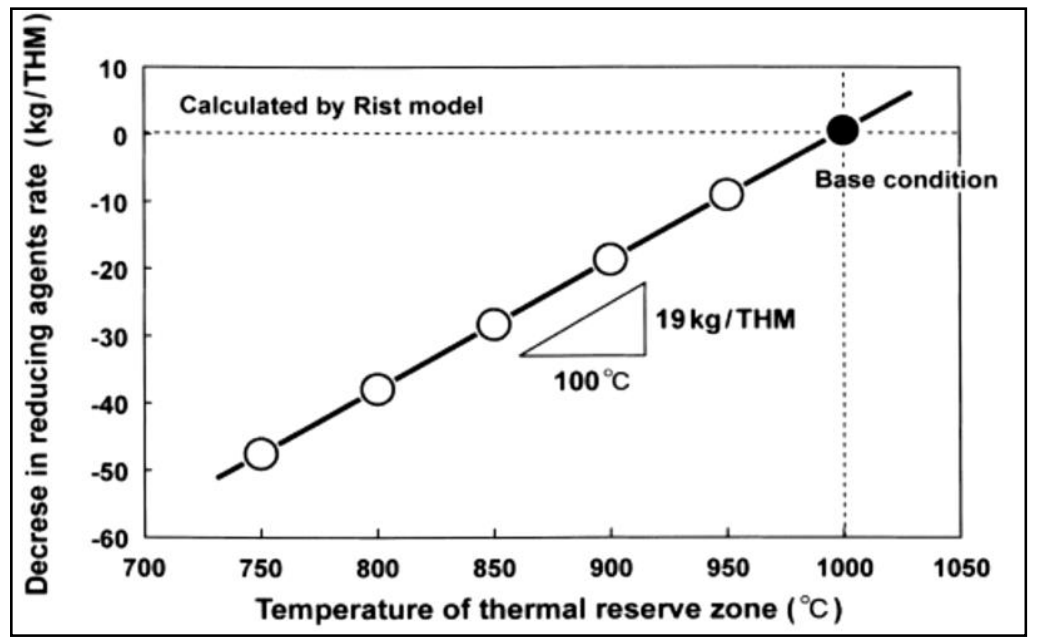

Fig. 6. Reducing agents rate and thermal reserve zone temperature [35].

It can be seen that lowering TRZT from $1000{ }^{\circ} \mathrm{C}$ to $750{ }^{\circ} \mathrm{C}$ can reduce the reducing agents consumption by $\sim 50 \mathrm{~kg} / \mathrm{tHM}$ due to the shifting of $\mathrm{Fe}_{\mathrm{met}} / \mathrm{FeO}$ equilibrium towards lower $\mathrm{CO} / \mathrm{CO}_{2}$ [35]. Nowadays, the majority of BFs in Europe, Japan, and others use nut coke at a different rate from $10-20$ to $70-100 \mathrm{~kg} / \mathrm{tHM}$ and more [37]. Although the charging of nut coke can contribute to saving of lump coke in $\mathrm{BF}$ and reducing the coke losses, it is still a type of fossil fuel that generates fossil $\mathrm{CO}_{2}$ emissions.

\section{Cold Bonded Briquettes and Pre-reduced Agglomerates}

The integrated steel plant involves a series of interconnected units such as cake making, sintering, BFs, basic oxygen furnaces, continuous casting, hot and cooled rolling. Each process generates a type of residues which are not suitable for further direct processing to the final product without pre-treatment. Such secondary materials include flue dust, filter dust, sludge, desulphurized scrap, Linz-Donawitz (LD) dust, coke fines, and mill scales. These materials contain a valuable amount of iron, lime, and carbon but it has a wide range of particle size, moisture content and chemical composition which make it unstable for direct recycling without sorting, preparation, and agglomeration to fulfill the specific requirements for charging back into BF. Intensive work was done to return generated by-products as substitutes to raw materials in the steel making process. Some of the steel plants recycled these materials during sintering of iron ore while other companies have a briquetting plant which can efficiently convert such secondary materials into cold bonded briquettes instead of the landfill. Cement is usually used as a binder to give the proper mechanical strength of top charged briquettes into the BF [3840]. Nowadays, cold bonded briquettes are charged at the rate of $100-120 \mathrm{~kg} / \mathrm{tHM}$ in some of BFs (e.g., SSAB in Sweden and Finland). These BFs are among the most efficient in the world in terms of $\mathrm{CO}_{2}$ efficiency [41]. Feasibility of recycling of high-zinc fraction of upgraded BF sludge to the hot metal (HM) in deS plant and BOF was recently studied [42]. The BF sludge was incorporated in self-reducing cold-bonded briquettes and pellets. Charging of developed briquettes or pellets into the hot metal showed endothermic reactions within the briquettes, which decreased the heating and melting rate in case of 
briquettes. Smaller size pellets were completely reduced within 8 minutes of contact with HM but still suffer from melt-in difficulties. On the other hand, the industrial trials demonstrated possible recycling of $10.9 \mathrm{~kg}$ of briquettes (containing $40 \%$ of BOF sludge) per tHM to the steel shop.

Beside the efficient utilization of by-products and waste fines, potentials were conducted on partial substitution of cement with biomass lignin from the pulp and paper industry [42, 43]. The replacement of cement with biomass lignin up to $25 \%$ has demonstrated good mechanical strength and enhanced the reducibility of the briquettes. The replacement of cement with lignin has increased the total carbon content while the sulfur content did not significantly change in the briquettes. Novel iron ore carbon composites were suggested to enhance the reduction rate of iron ore in the conventional $\mathrm{BF}$ and also alternative ironmaking processes (e.g., rotary hearth furnace and rotary kiln furnace) $[45,46]$. Such composites are very attractive to the aspects of energy saving and environmental protection. The studies carried out on iron ore-carbon composite have demonstrated higher reduction rate and lower coke consumption compared to the ordinary burden materials [47-52]. It was demonstrated that the starting temperature of carbon solution-loss reaction (Boudouard reaction) decreased as the degree of contact between iron ore and carbonaceous material increased $[52,53]$. The iron ore carbon composites are considered as a type of micro-reactors [54]. These composites are highly reactive due to the close contact between $\mathrm{Fe}_{2} \mathrm{O}_{3}$ and carbon particles, which enhances the reduction process $[55,56]$. The $\mathrm{CO}_{2}$ generated from the reduction of iron oxide (e.g., $\mathrm{FeO}+\mathrm{CO}=$ $\mathrm{Fe}+\mathrm{CO}_{2}$ ) and $\mathrm{CO}$ generated from the Boudouard reaction can be exchanged quickly in vacancies inside such type of micro-reactors. The trials in the large BF using cementbonded self-reducing pellets (SRP) were demonstrated with a maximum rate of $54 \mathrm{~kg}$ SRP/tHM [57]. Utilization of pre-reduced agglomerate (PRA) has recently been developed instead of conventional sinter to reduce the coke consumption and $\mathrm{CO}_{2}$ emissions in the BF. The new process is based on a partial reduction of sinter during the sintering process to produce PRA as can be seen in Fig. 7 [58].

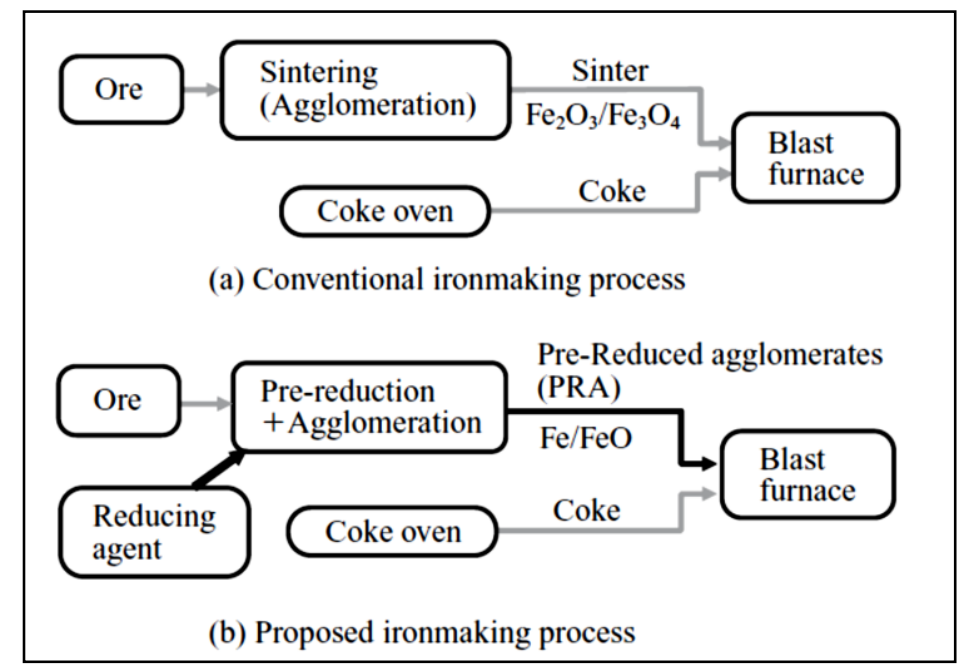

Fig. 7. Comparison of conventional and new agglomeration process [94]. 
It was reported that charging of PRA with a reduction degree of about $70 \%$ could reduce the $\mathrm{CO}_{2}$ emission from BF by $\sim 10 \%$, as shown in Fig. 8 [58]. Other work was directed to use non-coking coal with high ash and high volatile matter content for prereduction of iron ore nuggets [59]. As the metallic iron content in pre-reduced nuggets increases, the coke consumption and $\mathrm{CO}_{2}$ emission from BFs decrease.

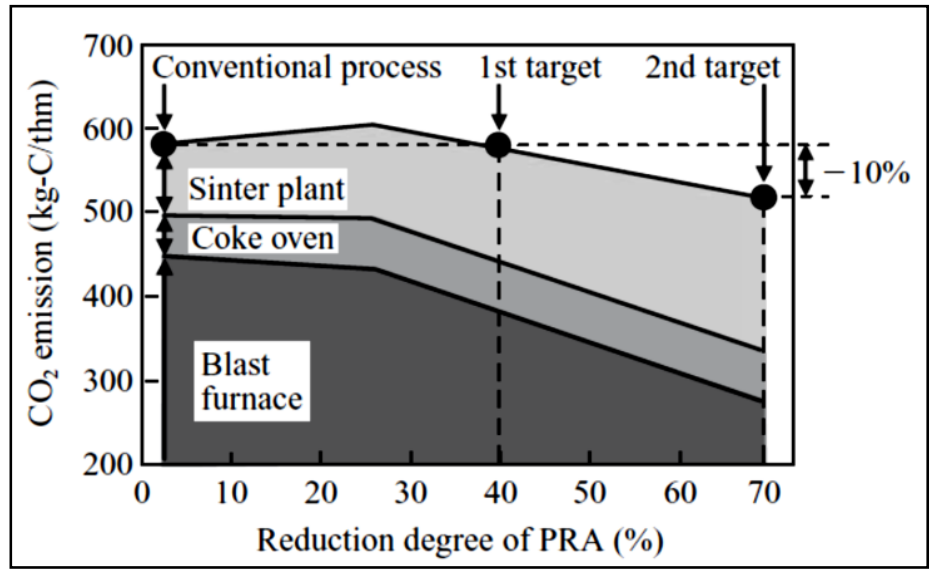

Fig. 8. Relationship between the reduction degree of PRA and $\mathrm{CO}_{2}$ emission [94].

Both cold bonded briquettes and self-reduced pellets have the potential to enhance the recycling rate, and it can efficiently participate in charging of pre-treated biomass to the BF. However, the deterioration of the mechanical strength by adding the biomass, the higher need for cement and the disintegration of such agglomerates by increasing the temperature in the BF shaft are still the main challenges limited its positive impact. Our recent research has discussed the effect of charging briquettes containing torrefied sawdust on the BF efficiency and process stability. The charging of bio-briquettes (39-64 $\mathrm{kg} / \mathrm{tHM}$ ) was demonstrated a positive impact on reducing coke consumption and $\mathrm{CO}_{2}$ emission [60].

\section{Renewable Biomass}

Increasing attention was recently paid on using renewable biomass as a source of heating and reducing agent instead of fossil fuels to mitigate the fossil $\mathrm{CO}_{2}$ emission in ironmaking [61]. Besides the environmental benefits related to the photosynthesis effect, the use of biomass and especially products of their thermal treatment will provide technological and economic advantages due to their unique properties represented in: very low sulphur content, high ratio of carbon to ash, relatively few and unreactive inorganic impurities as well as stable pore structure and high specific surface area [6264]. On the other hand, the presence of harmful elements in some types of biomass must be controlled because it could negatively affect the hot metal quality and production operation [65]. Low density and high affinity to absorb moisture from the atmosphere are also problematical for biomass utilization in the iron and steel industry. The results carried out using life cycle assessment methodology indicated that the use of charcoal in the integrated steelmaking route has the potential to reduce the greenhouse gas (GHG) footprint of steel by $0.69-1.21 \mathrm{t} \mathrm{CO}_{2} / \mathrm{t}$ steel without any credits, and by $0.91-1.61 \mathrm{t} \mathrm{CO}_{2} / \mathrm{t}$ steel with including by-product credits as given in Table 1 [66-68]. There is a strong 
potential for biomass to be used in the production of bio-coke, bio-sinter, bio-composites, replacement of nut coke, and replacement of pulverized coal in $\mathrm{BF}[69,70]$. It was reported that substitution of $20 \%$ of coke in $\mathrm{BF}$ with biomass could reduce the $\mathrm{CO}_{2}$ emission by $300 \mathrm{~kg} / \mathrm{tHM}$, which represents a $15 \%$ reduction in the total $\mathrm{CO}_{2}$ emission.

Table 1. Typical carbon addition rates in steelmaking and expected reduction in CO2 emissions [67].

\begin{tabular}{lccccc}
\hline $\begin{array}{l}\text { Application and } \\
\text { replaced carbon } \\
\text { source }\end{array}$ & $\begin{array}{c}\text { Typical } \\
\text { addition, } \\
\mathrm{kg} / \mathrm{tHM}\end{array}$ & $\begin{array}{c}\text { Charcoal } \\
\text { substitution } \\
\text { rate, } \%\end{array}$ & $\begin{array}{c}\text { Charcoal } \\
\text { amount, } \\
\mathrm{kg} / \mathrm{tHM}\end{array}$ & $\begin{array}{c}\text { Net emission reduction } \\
\mathrm{t}-\mathrm{CO}_{2} / \mathrm{t}- \\
\mathrm{Crude} \\
\text { steel }\end{array}$ & $\begin{array}{c}\% \text { of } \mathrm{CO}_{2} \\
\text { Emissions }\end{array}$ \\
\hline $\begin{array}{l}\text { Sintering solid fuel } \\
\text { Cokemaking }\end{array}$ & $76.5-102$ & $50-100$ & $38.3-102$ & $0.12-0.32$ & $5-15$ \\
$\begin{array}{l}\text { BF tuyere fuel } \\
\text { injection (PC) }\end{array}$ & $480-560$ & $2-10$ & $9.6-56$ & $0.02-0.11$ & $1-5$ \\
$\begin{array}{l}\text { BF nut coke } \\
\text { replacement }\end{array}$ & $150-200$ & $0-100$ & $0-200$ & $0.41-0.55$ & $19-25$ \\
$\begin{array}{l}\text { BF carbon/ore } \\
\text { briquette }\end{array}$ & $10-12$ & $0-100$ & $0-12$ & $0.06-0.12$ & $3-5$ \\
$\begin{array}{l}\text { Steelmaking } \\
\text { recarburiser }\end{array}$ & 0.25 & $0-100$ & $0-0.25$ & 0.001 & 0.04 \\
\hline \begin{tabular}{l} 
Totals \\
\hline
\end{tabular} & $761.75-$ & $0-100$ & $70.4-415.25$ & $0.69-1.25$ & 31.57 \\
\hline
\end{tabular}

The top charged bio-agglomerates (bio-coke, bio-sinter, and bio-composite) should be able to sustain the requirements of mechanical strength for BF; otherwise, it will deteriorate the process efficiency [61]. Also, any change in the BF input materials will directly affect the mechanism of mass and heat transfer, temperature profile and gas distribution inside the BF from raceway zone to the upper shaft. Intensive investigations were carried out to estimate the influence of bio-materials on the BF process. It was reported that charcoal could replace up to $20 \%$ of coke in the BF [71-73]. Charging of $20 \mathrm{~kg} / \mathrm{tHM}$ of charcoal could reduce the coke consumption by $30 \mathrm{~kg} / \mathrm{tHM}$ due to decreasing of the TRZT $[74,75]$. The porous structure of bio-sinter was demonstrated a higher reduction rate compared to that of conventional sinter [76]. Although the nut coke in the iron ore burden layers could be entirely replaced by small size charcoal, the low density and low strength of charcoal could lead to a segregation and dust generation in the BF shaft.

Iron ore-biomass composite is another option to reduce the energy consumption and $\mathrm{CO}_{2}$ emission in the $\mathrm{BF}$. These composites could enhance the reduction of iron oxide with closely adjacent carbon [52]. Recently, great attention was paid to investigate the influence of iron ore-carbon composite on the BF operation [77-81]. Hematite is completely reduced with woody biomass at temperature $\geq 1000{ }^{\circ} \mathrm{C}$ [82]. The reduction rate increased with temperature which attributed not only to the endothermic nature of the reduction reaction but also due to the faster decomposition of hydrocarbons (e.g., 
$\left.\mathrm{CH}_{4}\right)$ into fresh reducing gases $\left(\mathrm{CO}\right.$ and $\left.\mathrm{H}_{2}\right)$. A full reduction of iron ore to metallic iron was achieved by $30 \mathrm{wt} . \%$ of sawdust [83]. Although the biomass seems like an efficient reducing agent for iron ore in lab-scale tests, the practical application in large BF is still limited. The main reason is the low crushing strength of such iron ore-biomass composites. The weak strength of iron ore-biomass composite compared to iron ore-coal composite is attributed to the absence of coal thermal plasticity. The thermal plasticity of coal provides the proper mechanical strength of iron ore-coal composites. Also, the volatile matter of biomass is often escaped at relatively low temperature before starting the reduction of iron oxides. For this reason, a special design of iron ore-biomass composite is still required to enhance the utilization of volatile biomass matter in the reduction of iron oxides.

Further development and modifications are still required to enhance the application of iron ore-biomass composites in the modern BF. In order to overcome the obstacle of biomass top charging, the tuyeres injection provides a flexible option for biomass utilization in the large modern BF. The next section will discuss the development of tuyeres injections.

\section{Development in Tuyeres Injections}

Besides the development of the top charging system and top charging materials, tremendous modifications were done in the lower part of the BF shaft. Maximizing the auxiliary fuels injection into the BF becomes one of the vital options to lower the operating cost and maximize productivity. Usage of cheaper fuels and $\mathrm{H}_{2}$ rich materials for partial substitution of metallurgical coke can be effectively reduced the $\mathrm{CO}_{2}$ emission. The next sub-sections will thoroughly discuss the tuyere injection of different auxiliaries' materials into the $\mathrm{BF}$.

\section{Pulverized Coal Injection (PCI)}

PCI is one of the essential methods to enhance BF profitability. The majority of $\mathrm{BFs}$ all over the world apply $\mathrm{PC}$ due to the relatively lower cost of coal compared to other fuels beside the beneficial effect on the BF efficiency. Injection of PC into the BF provides various economic and operational benefits [84]. These benefits are including (i) lower consumption of expensive coke, (ii) replacing high-rank expensive coal with low grade cheaper coals, (iii) longer life period of coke oven, (iv) higher BF productivity, (v) higher flexibility in BF operation, (vi) improving the hot metal quality, and (vii) lower $\mathrm{CO}_{2}$ emissions. Recently, stable BF operation with PCI rates of around $200 \mathrm{~kg} / \mathrm{tHM}$ and coke rate below $300 \mathrm{~kg} / \mathrm{tHM}$ was successfully maintained. The replacement ratio of PC for coke is about 1.0 at the injection rate up to $200 \mathrm{~kg} / \mathrm{tHM}$ [85]. At higher PCI (>200 $\mathrm{kg} / \mathrm{tHM}$ ), there is a reduction in the incremental replacement ratio of PC for coke. In contrast with other fuels which could be injected through tuyeres, PC has the minimum negative impact on the raceway flame temperature and therefore, it has the highest possible injection rate than other fuels. The combustion of $\mathrm{PC}$ in the raceway is a complex process that requires high control of various parameters. Efficient PCI is obtained by convenient coal treatment, including the control of moisture content and grain size. The proper mixing of $\mathrm{PC}$ with the hot blast, uniform distribution of $\mathrm{PC}$ across all tuyeres, low $\mathrm{N}_{2}$ input into the $\mathrm{BF}$ and maximizing retention time of coal in the tuyeres are necessary to achieve high combustion efficiency. The injection of coal through the tuyeres is certainly not a new technology, but it was recently developed to sustain an optimum 
condition. The enriched oxygen hot blast $\left(1100-1250{ }^{\circ} \mathrm{C}\right)$ is injected into the blowpipe at velocity $100-200 \mathrm{~m} / \mathrm{s}$. The coal/gas mixture (e.g., $150 \mathrm{~kg}$ coal/tHM) is injected by lance into the blowpipe at a rate equal of $150 \mathrm{~g} \mathrm{coal} / \mathrm{m}^{3}$ of the blast.

The combustion of the PC takes place in three main steps. In the first step, the volatile matters of coal are released and combusted with the surrounding oxygen. This volatiles generates different gases including $\mathrm{N}_{2}, \mathrm{CO}_{2}, \mathrm{H}_{2} \mathrm{O}$ and small portions of $\mathrm{CO}, \mathrm{H}_{2}$, and $\mathrm{C}_{\mathrm{x}} \mathrm{H}_{\mathrm{y}}$. In the second step, the combustion of residual char takes place, which has a slower rate than the combustion of volatiles. In the third step, ash is released after the complete combustion of char [86, 87]. Fig. 9 illustrates a schematic view of the tuyeres and different reaction zones in the raceway during PC injection [88]. The raceway consists of: (i) PC de-volatilization zone, (ii) oxidation zone and (iii) solution loss reaction zone.

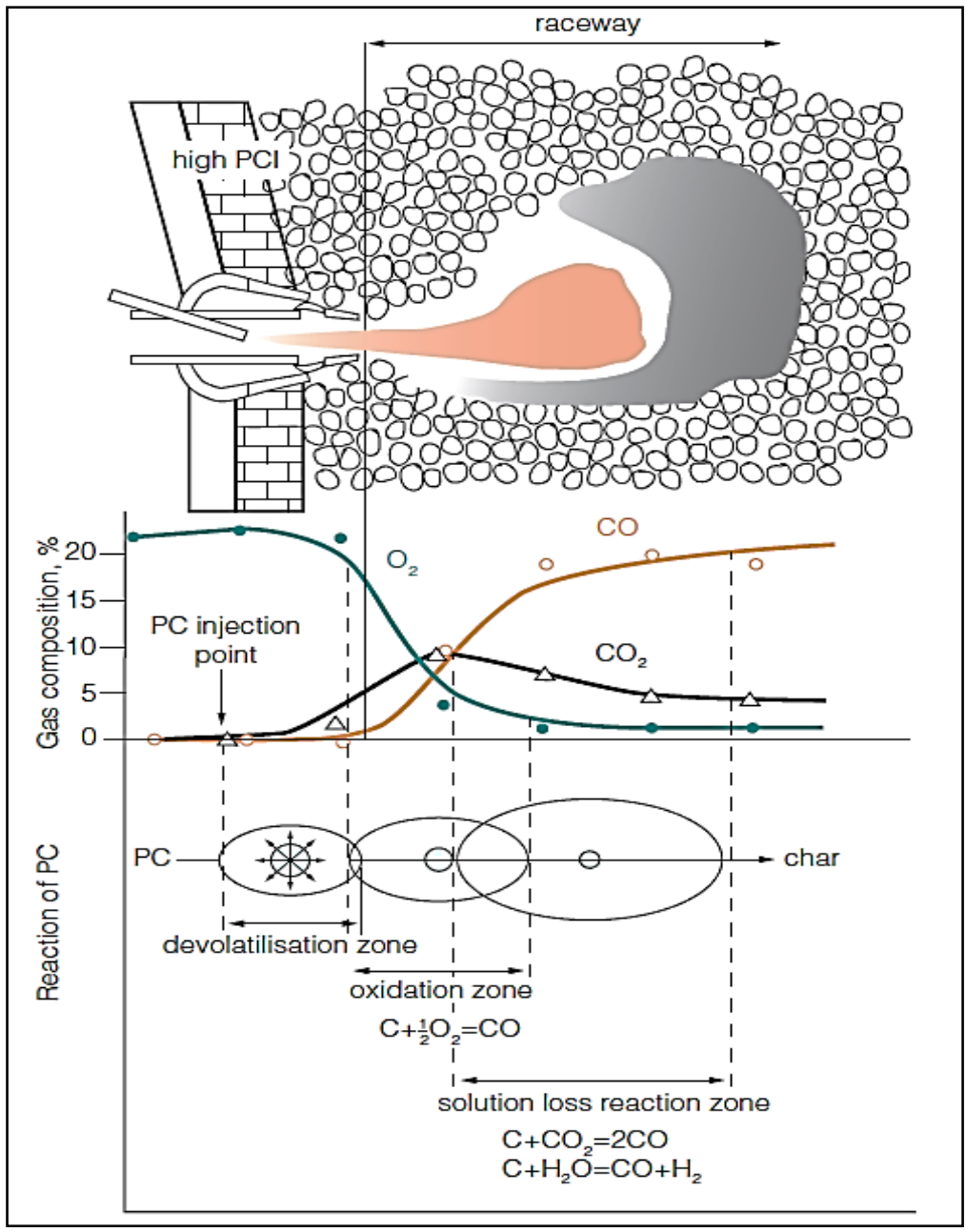

Fig. 9. The schematic diagram for $P C$ reaction in raceway $[87,88]$. 
The concentration of oxygen is sharply decreasing in the oxidation zone due to its reaction with the carbon of coke and coal to produce $\mathrm{CO}_{2}$ as given in Eq. 1. As the oxygen concentration decreases, the solution loss reaction by $\mathrm{CO}_{2}$ or steam takes place, as given in Eqs. 2 and 3, and the concentration of $\mathrm{CO}$ increases while $\mathrm{CO}_{2}$ decreases. Therefore, the reaction rate of $\mathrm{PC}$ is dependent on the oxygen content in the hot blast. The PC injection rate, blast condition (temperature, pressure, moisture, and oxygen content), coal properties (carbon content, ash content, VM content, particle size), lance construction and properties of top charged coke are important factors affecting the combustion efficiency of coal in the raceway.

$$
\begin{aligned}
& C_{(s)}+O_{2(g)}=C O_{2(g)} ; \Delta H^{o}=-393.5 \mathrm{~kJ} / \mathrm{mol} \\
& C_{(s)}+C_{2(g)}=2 C O_{(g)} ; \Delta H^{o}=+172.467 \mathrm{~kJ} / \mathrm{mol} \\
& C_{(s)}+H_{2} O_{(g)}=C O_{(g)}+H_{2(g)} ; \Delta H^{o}=+131.294 \mathrm{~kJ} / \mathrm{mol}
\end{aligned}
$$

The Raceway Adiabatic Flame Temperature (RAFT) is defined as the temperature that the raceway gas reaches as soon as all $\mathrm{C}, \mathrm{O}_{2}$, and $\mathrm{H}_{2} \mathrm{O}$ are converted to $\mathrm{CO}$ and $\mathrm{H}_{2}$. The RAFT is normally in the range of $1900-2300{ }^{\circ} \mathrm{C}$ based on PCI rate, PC quality, blast temperature, blast moisture, and oxygen enrichment. The RAFT is theoretically calculated from Eq. 4 [89] based on mass and heat balance. With increasing PCI, $\mathrm{O}_{2}$ enrichment is an important factor that affects the RAFT [89]. The higher PCI rate, the higher $\mathrm{O}_{2}$ enrichment is required to sustain the heat balance in the upper and lower part of the furnace. Too low RAFT results in very low top gas temperature, which will delay the drying of the cold top-charged burden and consequently make the upper shaft less efficient. On the other hand, too high $\mathrm{O}_{2}$ enrichment in the blast is accompanied by relatively high RAFT, which will result in an erratic descend of the burden. Therefore, the oxygen content in the hot blast has to be optimized very carefully to reach the proper RAFT and shaft efficiency.

$$
\begin{gathered}
R A F T=1489+0.82 \cdot B T-5.705 \cdot B M+52.778 \cdot O E-18.1 \cdot \frac{\text { Coal }}{W C} \cdot 100- \\
43.01 \cdot \frac{\text { oil }}{W C} \cdot 100-27.9 \cdot \frac{T a r}{W C} \cdot 100-50.66 \cdot \frac{N G}{W C} \cdot 100
\end{gathered}
$$

Where; BT: Blast Temperature, ${ }^{\circ} \mathrm{C}$; BM: Blast moisture, $\mathrm{g} / \mathrm{m}^{3}$ STP dry blast; OE: Oxygen enrichment $\left(\% \mathrm{O}_{2}-21\right)$; Oil: dry oil injection rate, $\mathrm{kg} / \mathrm{tHM}$; Tar: dry tar injection rate $\mathrm{kg} / \mathrm{tHM}$; Coal: dry coal injection rate, $\mathrm{kg} / \mathrm{tHM}$; NG: Natural gas injection rate, $\mathrm{kg} / \mathrm{tHM}$; WC: Wind consumption, $\mathrm{m}^{3} / \mathrm{tHM}$.

The transit time of the injected coal particles in the raceway is in range of 20-30 ms [90]. Within such limited time, it is crucial to assure that most of the coal is gasified before escaping the raceway region; otherwise, it will be swept into the coke bed and consequently deteriorates the permeability of active coke zone [90, 91]. Fig. 10 summarizes the various problems which could be occurred due to the high injection rate of PC $[87,88]$. 


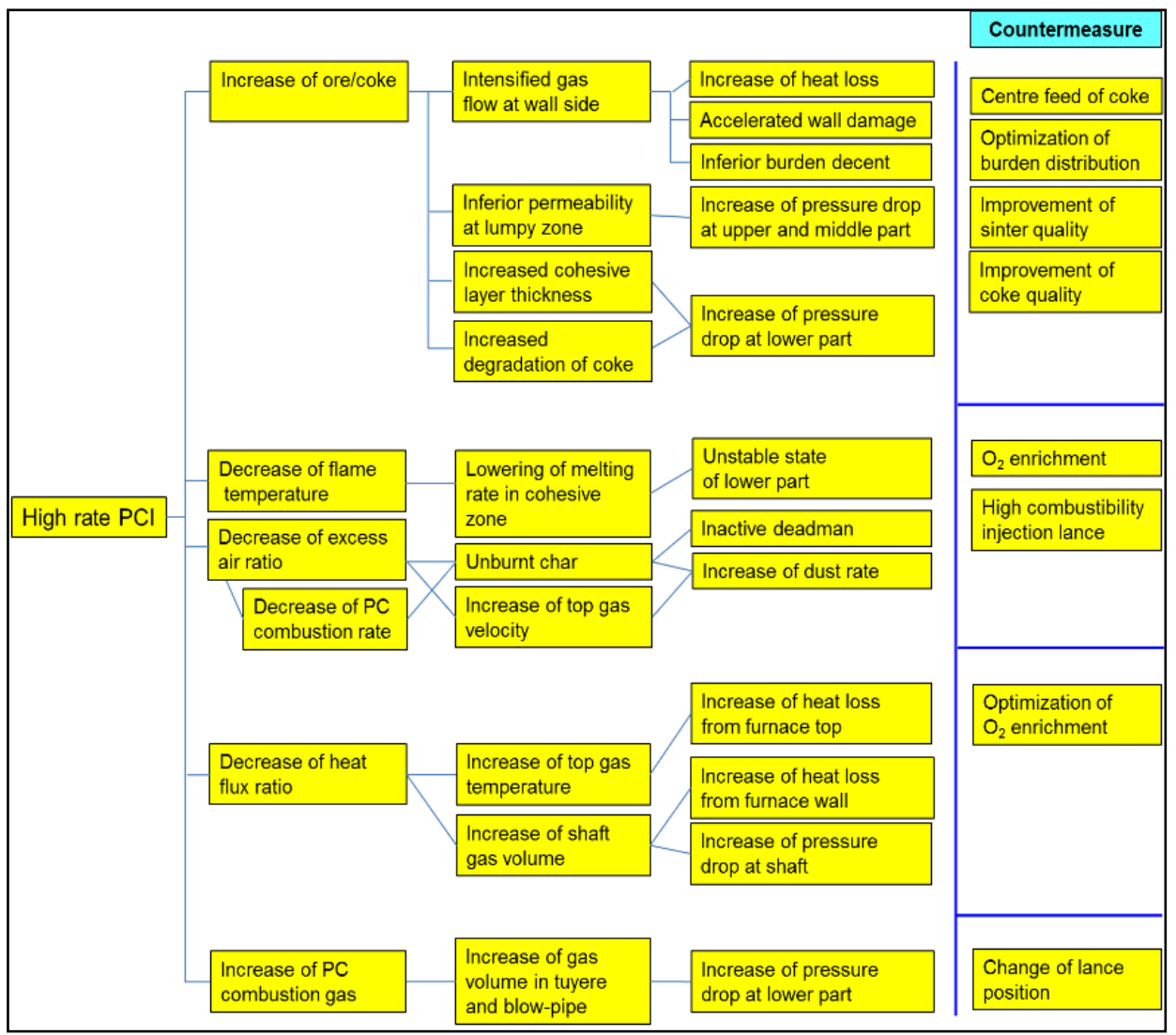

Fig. 10. Expected technical issues and countermeasure at a high rate of PCI into the blast furnace [87].

The fine char particles tend to block the bed voids and consequently disturb the gas flow and increase the pressure drop inside the furnace, reduce the permeability of liquids and gases in the cohesive zone and reduce the shaft efficiency and the furnace productivity $[92,93]$. Coals with higher volatile matter (VM) content exhibit superior combustibility in raceway due to the higher reactivity, however coals with very high VM contain less carbon and hence the combustion efficiency in the raceway will be reduced [11]. Moreover, at high PCI, sulfur and phosphorous should be kept as low as possible to avoid the negative effect on the hot metal quality. The PCI is considered one of the recent significant modifications in the BF technology which provided good opportunity to reduce the load on cokemaking, utilize poor quality coal resources, and to reduce the overall costs. One of the main challenges is the decreasing of coke-to-coal replacement ratio by increasing the PCI rate higher than $200 \mathrm{~kg} / \mathrm{tHM}$. Further research and development on PCI technologies and understanding the behavior of PC at high injection rate $(200-300 \mathrm{~kg} / \mathrm{tHM})$ to the $\mathrm{BF}$ are still needed. 


\section{Oil and Natural Gas Injection}

The injection of oil and natural gas (NG) into the BF were firstly implemented before PC, but the energy crisis during the 1970s resulted in more attention to PCI. Nowadays, the countries which are rich with oil and NG are still injecting these fuels into the BF to reduce coke consumption. The injection of 1.0 ton of oil or $\mathrm{NG}$ can replace 1.2 tons of coke $[94,95]$. The average consumption of $\mathrm{NG}$ is $70-100 \mathrm{~m}^{3} / \mathrm{tHM}(\sim 50-70$ $\mathrm{kg} / \mathrm{tHM})$ but often exceeds to $150-170 \mathrm{~m}^{3} / \mathrm{tHM}(\sim 105-120 \mathrm{~kg} / \mathrm{tHM})$. The operation of BFs using NG and oxygen-enriched blast is called composite blast technology. With oxyoil technology, the amount of injected oil could reach a level of $180 \mathrm{~m}^{3} / \mathrm{tHM}(130$ $\mathrm{kg} / \mathrm{tHM})$. Oil and $\mathrm{NG}$ are decomposed and combusted in the BF raceway. The decomposition and combustion of hydrocarbons generate $\mathrm{CO} / \mathrm{CO}_{2}$ and $\mathrm{H}_{2} / \mathrm{H}_{2} \mathrm{O}$. The $\mathrm{CO}_{2}$ and $\mathrm{H}_{2} \mathrm{O}$ are in-situ react with the carbon of coke and PC or with hydrocarbons of NG to finally generate $\mathrm{CO}$ and $\mathrm{H}_{2}$. The participation of hydrogen in the reduction of iron oxide leads to a decrease of $\mathrm{CO}_{2}$ emissions. The heavy oil and NG have a higher percentage of hydrocarbons compared to coal/coke and thereby the endothermic effect of these hydrocarbons results in a higher drop in RAFT [10]. It was estimated that the RAFT would be decreased by $350-450{ }^{\circ} \mathrm{C}$ per $100 \mathrm{~m}^{3} / \mathrm{tHM}$ of $\mathrm{NG}$ injection, $300-350{ }^{\circ} \mathrm{C}$ per 100 $\mathrm{kg} / \mathrm{tHM}$ of heavy oil injection, $200-250{ }^{\circ} \mathrm{C}$ per $100 \mathrm{~m}^{3} / \mathrm{tHM}$ of coke oven gas injection, $80-120{ }^{\circ} \mathrm{C}$ of low volatile coal injection and $150-220{ }^{\circ} \mathrm{C}$ of high volatile coal injection [10]. Recent studies indicated that the rate of NG injection into the BF could be increased significantly by injecting part of the NG in the shaft of the furnace. This will reduce the endothermic effect of NG injection on the RAFT and the total oxygen consumption would be slightly lower compared with the tuyere-only injection [96]. A mathematical model based on the heat balance in the bottom segment of the BF was developed to calculate the maximum injected amount of $\mathrm{NG}\left(\mathrm{V}_{N G}^{\max }\right)$ to attain the minimum value of the theoretical flame temperature, minimum possible coke consumption $\left(C_{\min }\right)$ and the minimum direct reduction $\left(\mathrm{rd}_{\min }\right)$ [97, 98]. It was reported that the minimum coke consumption will be obtained when the coke carbon which is used as a source of heat is equal to the coke carbon which is consumed in the reduction processes [97]. Based on the developed model, $\operatorname{rd}_{\text {min }}, C_{\min }$ and $\mathrm{V}_{N G}^{\max }$ can be theoretically calculated from Eqs. 5-7; respectively.

$$
\begin{aligned}
& r d_{\text {min }}=\frac{\frac{1}{\bar{\eta} c o}-n\left(2 \frac{\bar{\eta}_{H_{2}}}{\bar{\eta} C O}-\frac{\bar{Q}_{C H_{4}}}{\bar{Q}_{C_{\varnothing}}}+1\right)-C_{i}^{h}}{\frac{1}{\bar{\eta} c o}+\frac{\Delta H_{T 1}}{\bar{Q}_{C_{\varnothing}}}+1} \\
& C_{\text {min }}=\frac{1-r d_{\text {min }}}{\bar{\eta} c o}-2 n \\
& V_{N G}^{\max }=\frac{\frac{22.4 F e_{e}}{M_{F e}}\left(2 \frac{1}{\bar{\eta}_{C O}}-C_{i}^{h}\right)}{2+\frac{Q_{H_{2}}}{\bar{\eta} c o}-\frac{Q_{C H_{4}}}{Q_{C_{\varnothing}}}+1}\left[\mathrm{~m}^{3}\left(\mathrm{CH}_{4}\right) t^{-1} H M^{-1}\right]
\end{aligned}
$$

where, $\bar{\eta}$ co: degree of $\mathrm{CO}$ utilization for $\mathrm{FeO}$ reduction; $\bar{\eta}_{\mathrm{H}_{2}}$ : degree of $\mathrm{H}_{2}$ utilization for FeO reduction; $\bar{Q}_{\mathrm{CH}_{4}}$ : heat given by the combustion of 1 mole of $\mathrm{CH}_{4}$ at thermal reserve zone in the furnace $\left(900^{\circ} \mathrm{C}\right) ; \bar{Q}_{C_{\varnothing}}$ : heat given by burning of coke carbon at thermal reserve zone in the furnace $\left(900^{\circ} \mathrm{C}\right) ; \Delta H_{T 1}$ : enthalpy of direct reduction of iron oxide; $\mathrm{M}_{\mathrm{Fe}}$ : molar mass of $\mathrm{Fe} ; \mathrm{Fe}_{e}$ : iron content in hot metal. 


\section{Off-Gases Injection}

Efficient utilization of integrated steel plant top-gases becomes necessary to achieve profitability to steel mill operation from both economic and environmental aspects. The major fuel gases that could be recovered in the integrated steelworks are including BF gas (BFG), coke oven gas (COG), and basic oxygen furnace gas (BOFG). The chemical compositions of these gases are given in Table 2 [99].

The off-gas from the BF is the lowest from heat content and the highest from the generated amount in an integrated steel plant. Top Gas Recycling BF (TGR-BF) technology was studied in one of the largest European project, namely Ultra Low $\mathrm{CO}_{2}$ Steel (ULCOS) $[100,101]$. The four breakthrough technologies identified were: (i) Top Gas Recycling $\mathrm{BF}$ (TGR-BF) with $\mathrm{CO}_{2}$ Capture and Storage (CCS); (ii) HIsarna Smelting Reduction with CCS; (iii) Ultra Low $\mathrm{CO}_{2}$ direct Reduction (ULCORED) with CCS; and (iv) Electrolysis. TGR-BF aimed at lowering the usage of fossil carbon (coke) via re-usage of the reducing agents $\left(\mathrm{CO}\right.$ and $\left.\mathrm{H}_{2}\right)$ after the removal of the $\mathrm{CO}_{2}$ from the BF top gas. In order to reach the $50 \% \mathrm{CO}_{2}$ reduction, the application of $\mathrm{CO}_{2}$ capture and storage (CCS) technology is necessary. Heat and mass balance models were used to identify the carbon consumption at different hot and cold TGR as given in Fig. 11 [102].

Table 2. Typical chemical composition of top-gases in the integrated steel mill [99].

\begin{tabular}{lcccccccc}
\hline $\begin{array}{l}\text { Type of } \\
\text { gas }\end{array}$ & $\mathrm{H}_{2}$ & $\mathrm{CO}$ & $\mathrm{CH}_{4}$ & $\begin{array}{c}\mathrm{C}_{2} \mathrm{H}_{6} \\
\text { vol.\% }\end{array}$ & $\mathrm{CO}_{2}$ & $\mathrm{~N}_{2}$ & $\mathrm{MJ} / \mathrm{Nm}^{3}$ & $\mathrm{Nm}^{3} / \mathrm{t}$ \\
\hline COG & 63 & 5.8 & 22 & 2.9 & 2.0 & 4 & 17.9 & $410-560$ \\
BOFG & - & 55 & - & - & 15 & 30 & 8.95 & $50-100$ \\
BFG & 2.6 & 20.3 & - & - & 24.3 & 52.8 & 3.37 & $1414-1500$ \\
\hline
\end{tabular}
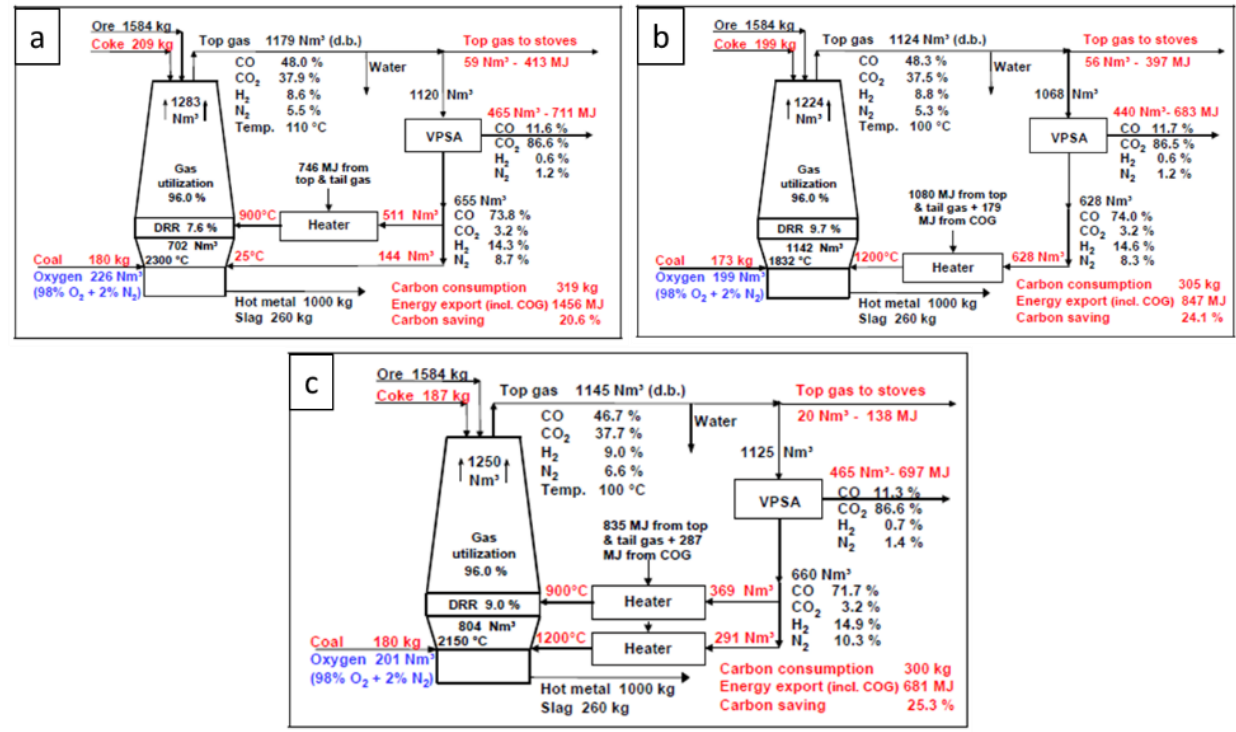

Fig. 11. Heat and mass balance model for TGR-BF at [102]: (a) TGR hot at the stack and cold at main tuyeres, b) TGR hot at main tuyeres, $c$ ) TGR hot at the stack and main tuyeres. 
The highest carbon saving $(25.1 \%)$ is achieved by hot TGR at stack and tuyeres injection. Trials were conducted at LKAB s' Experimental BF (EBF) in Luleå, Sweden $[103,104]$. The EBF was modified and a gas separation plant based on VPSA technology was built near the EBF. Although the tests at the EBF are considered successful, the industrialization of the ULCOS-BF technology requires an additional scale-up step. The $\mathrm{COG}$ has the largest net calorific value in the range of $16.4-18 \mathrm{MJ} / \mathrm{Nm}^{3}$ (STP) compared to that of either BOFG $\left(\sim 8.8 \mathrm{MJ} / \mathrm{Nm}^{3}\right)$ or BFG $\left(3.0-3.7 \mathrm{MJ} / \mathrm{Nm}^{3}\right)[105,106]$. The specific amount of generated coke oven gas is in the range of $410-560 \mathrm{Nm}^{3} / \mathrm{t}$ of coke while the amount of BOFG is in the range of $50-100 \mathrm{Nm}^{3} / \mathrm{t}$ of steel in the suppressed combustion system, and it could reach $500-1000 \mathrm{Nm}^{3} / \mathrm{t}$ of steel in the open combustion system. The annual worldwide metallurgical coke production is more than $500 \mathrm{Mt}$ which is produced from about $650 \mathrm{Mt}$ of coking coals [107]. The cokemaking process is accompanied by more than 310 billion $\mathrm{Nm}^{3}$ of COG [108]. The COG is currently used in the heating of $\mathrm{BF}$ stoves, ignition furnaces in sintering plant, heating furnace in rolling mills and electric power generation in power plant $[105,106]$.

The estimations which were carried out on optimizing the energy consumption in the integrated iron and steel works indicated that the utilization of COG for power generation is not always the optimal credits [105]. The composition of COG, which is rich with hydrogen, is attracting much attention for its utilization in the reduction processes [109-112]. The flexibility of COG utilization in the integrated steel plant for DRI production through the addition of Midrex process is expected to be also an efficient method that can introduce many benefits to the integrated steel mill [106]. The merging of the "traditional" ironmaking BF with the "alternative" direct and smelting reduction processes is an innovative approach to achieve the economic and environmental targets of higher production and lower emissions. The recent studies which were carried out to evaluate the reduction potential of original coke oven gas (OCOG) and reformed coke oven gas (RCOG) for direct reduction of iron ore pellets compared to reformed natural gas (RNG) indicated the high efficiency of these gases for DRI production [113-116]. Optimization of the reforming process of coke oven gas is crucial to avoid the severe crack of pellets in the case of reduction with RCOG and the carbon deposition in the case of OCOG. The reduction potential of COG with/without mixing with converter gas (BOFG) was studied for natural lump ore at $800-1050{ }^{\circ} \mathrm{C}[116,117]$. It was reported that the highest reduction rate was achieved with RCOG followed by OCOG. The reduction rate was decreased in the order of RCOG $>$ OCOG $>$ RNG $>$ OCOG-BOFG $>$ RCOG-BOFG at $900-1050{ }^{\circ} \mathrm{C}$. The injection of COG into the $\mathrm{BF}$ through tuyeres influences the raceway conditions and iron ore reduction. The combustion of COG hydrocarbons in the front of tuyeres by blast oxygen results in the generation of carbon monoxide and hydrogen gases, which increase the potential of reducing gas on account of inert $\mathrm{N}_{2}$ [118]. The theoretical calculation and commercial trails, which carried out on the replacement of NG with coke oven gas in BF showed lower coke consumption and higher hot metal production [119]. The high efficiency of COG is because it contains 3.5-4.0 times less hydrocarbons compared to that of NG [10]. This improves the combustion in the tuyere hearth, activate coke column, and increase gases utilization in the furnace. The injection of COG into the $\mathrm{BF}$ is practiced in some countries with different injection rates from about 30 to 280 $\mathrm{m}^{3} / \mathrm{tHM}[120,121]$. It was reported that the maximum level of COG injection into the BF is $100 \mathrm{~kg} \mathrm{COG} / \mathrm{tHM}$ according to the thermochemical conditions while the replacement ratio is 0.98 ton of coke/t of COG [122]. 


\section{Waste Plastics and Biomass Injection}

Recycling and utilization of waste plastics have received increasing interest in recent decades. The majority of this material is currently being landfilled or incinerated, which causes environmental problems. The combustion of waste plastics generates hazardous pollutants, such as dioxins/furans, as well as undesirable carbon dioxide. The waste plastics can be efficiently utilized in BFs as an alternative reducing agent and as a source of heat to reduce the coke consumption. As the plastics contain hydrogen and carbon it can also be provided additional benefits similar to oil and NG injection into the $\mathrm{BF}$. Due to the difficulty of waste plastics crushing, coarse particles were preferred to inject into the furnace; however, the fine particles are better in combustion in the raceway. Therefore, a technology for fine pulverization of waste plastics was developed and implemented in a full-scale industrial BF in Japan. Since the collected waste plastics are heterogeneous mixture form different types, it is recommended to conduct heat treatment at $200{ }^{\circ} \mathrm{C}$ before its injection into the BF. The pre-treatment will generate a homogenous pulverized waste plastic mixture [123]. Moreover, the pre-treatment of waste plastics will perform de-chlorination for waste plastics which contain chlorine such as polyvinyl chloride (PVC) and hence avoid the corrosive effect on the BF tuyeres and the refractory materials in hearth lining. The theoretical limit of waste plastics injection is estimated to be $70 \mathrm{~kg} / \mathrm{tHM}$ while the higher injection rate will result in problems similar to that obtained with the relatively high PCI. Every ton of plastics used in the BF can replace $750 \mathrm{~kg}$ of coke [124]. Injection of waste plastics into the $\mathrm{BF}$ could reduce the $\mathrm{CO}_{2}$ emissions by $30 \%$ due to the higher $\mathrm{H}_{2}$ content [125]. On the other hand, the cost of waste plastic collection and treatment is still representing one of the main challenges for its implementation in ironmaking. Efficient and effective systems are required to secure a sustainable and reliable supply of waste plastic into the BF.

Renewable biomass represents one of the vital options to mitigate $\mathrm{CO}_{2}$ emissions in the steel industry. The recent analysis of the long-term potential for renewable energy in industrial applications suggested that up to $21 \%$ of total energy use in the manufacturing industry in 2050 could be covered from renewable origin materials [126]. This will compensate for about 50 exajoules $\left(10^{18} \mathrm{~J}\right)$ per year (EJ/year) from the total energy (230 EJ/year) used in the industrial sectors. Utilization of renewable biomass in the industrial sector has the potential to reduce GHG emissions by $10 \%$ in 2050 [127]. As the top charging of biomass into the modern BF still suffers from some problems which are related to the lower mechanical strength and the high volatile matter compared to coke, the tuyeres injection provides a flexible option for biomass utilization. In this case the mechanical strength is not required; however, the combustion behavior of biomass is a very important factor affecting the RAFT. A static heat and mass balance model was applied to investigate the substitution rate of biomass products (charcoal, torrefied material, and wood pellets) for PCI $[128,129]$. It was found that $166.7 \mathrm{~kg} / \mathrm{tHM}$ charcoal could fully replace $155 \mathrm{~kg} / \mathrm{tHM}$ PCI. The torrefied material and wood pellets could be partially replaced PCI by $22.80 \%$ and $20 \%$ respectively [129]. The reactive structure of charcoal improves the combustion process in raceway to become comparable to that of coal [130]. It was reported that the maximum injection rate of charcoal would be in the range of $200-220 \mathrm{~kg} / \mathrm{tHM}$ which could reduce the net $\mathrm{CO}_{2}$ emissions by $40 \%$ [131]. Besides the environmental benefits, the injection of charcoal will result in a lower amount of slag and higher production rate due to the low sulfur and ash content and higher content of $\mathrm{CaO}$ compared to PCI [132]. Although the investigations and the commercial trails 
conducted on biomass injection into the BF demonstrated many benefits, its application is not practiced yet in the large modern BFs. The practical limitations could be summarized in four main points [131]: (i) less calorific value of biomass products compared to coal which required efficient pre-treatment and pyrolysis, (ii) difficulties in biomass injection at high rate due to the porous nature and the low density which required an optimization for the injection process, (iii) wider particle size distribution of biomass after grinding which required an efficient sieving to get the proper particle size for injection and (iv) higher alkalis in biomass products which should be controlled and minimized before utilization to avoid its negative impact on the refractory materials. Also, the higher cost of biomass products compared to that of fossil fuels represents another challenge for its implementation. The availability and characteristics of different sources of biomass and the suitable pretreatment technologies for their upgrading are discussed and evaluated elsewhere [132].

\section{Potentials of Waste Heat Recovery (WHR)}

Within the steel industry, 20-60\% of the primary energy is transformed into waste heat. These waste heats are carried in different sources, such as flue gas, water/liquid streams and hot solid at different temperature levels. Some amounts of waste heat can be utilized within the process, or power plant, while the rest is flared or lost. New technologies are under development in order to economically maximize the recovery of waste heat recovery.

\section{Analysis of Waste Heat in Steel Plant}

In some of the globally integrated steel plants, with total production around $60 \mathrm{Mt}$ of steel, the waste heat is varied from about $20 \%$ up to $60 \%$ as can be seen in Fig. 12(a) [133]. The waste heat comes from heat conduction, convection, and radiation of hot surfaces, heated products, and by-products.

The waste heat carriers are mainly hot slag from BF and BOF, hot flue gases from EAF, BOF, reheating furnaces and heat treatment furnaces, hot air from annealing furnace and hot water from reheating furnace and annealing furnace as shown in Fig. 12(b) [133]. The highest temperature streams are demonstrated by BOF gas, EAF gas, and BF slag. It can be seen that the heat in the iron and steel industry is mainly stored in hot products, molten slag, and waste gas. About $55 \%$ of energy is stored in the hot products while around $45 \%$ is lost as waste heat with solid by-products and exhaust gases [134]. Nowadays, three main sources of waste heat are commonly recovered in steel plants for steam production; COG, BOF gas, and EAF gas. The produced steam can be used for different internal usage in the plant and it can also be used for power generation for an internal and external user. On the other hand, the waste heat recovery from reheating furnaces and annealing furnaces are more challenging. Production of different grades of steel is required to control and adjust the parameters of reheating and annealing to achieve specific mechanical properties of steel. The fluctuations of production rate and product type beside the relatively low temperature of streams are required type of highly flexible heat recovery unit to adapt with these variations; otherwise, it will harm the operation stability. 


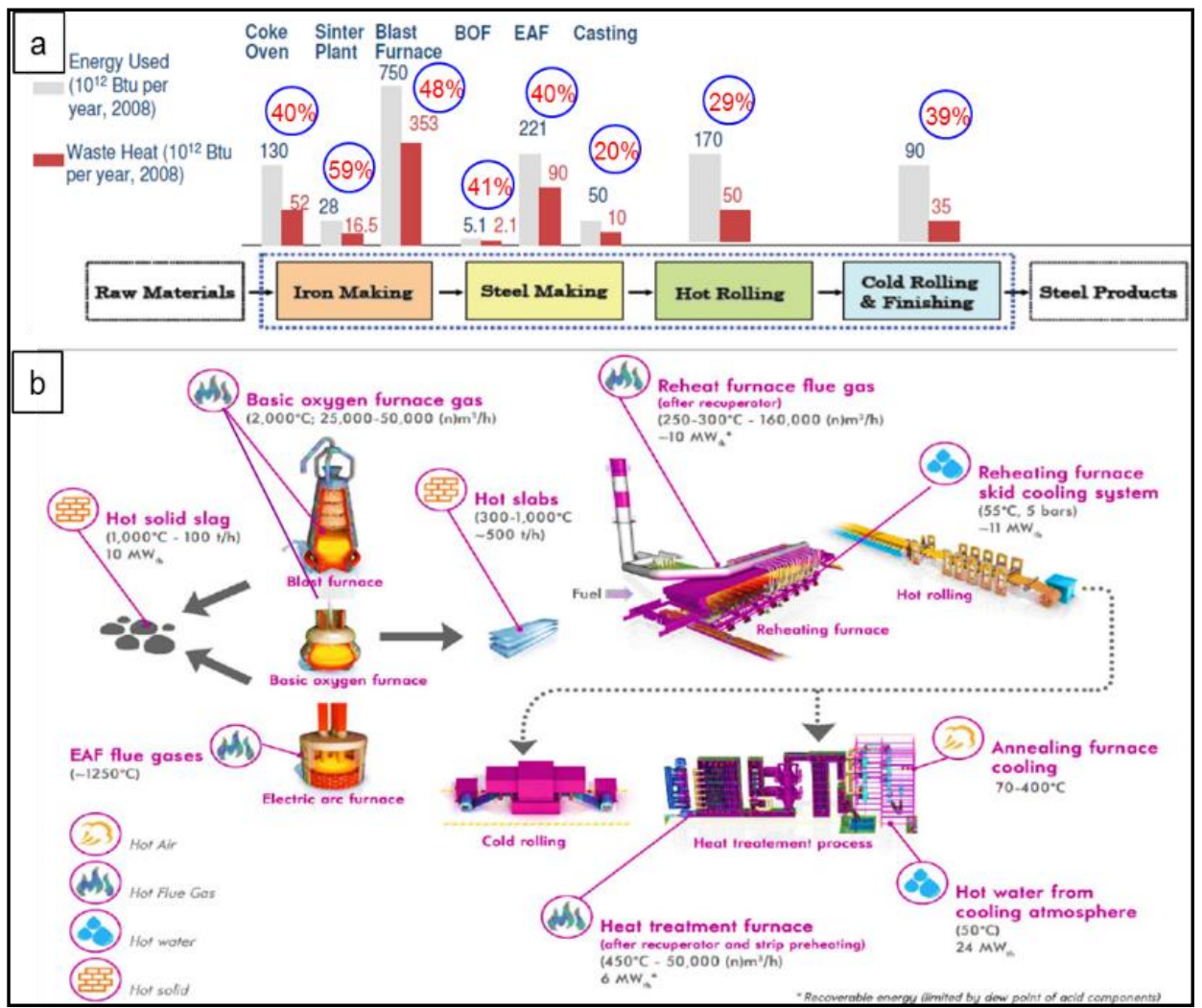

Fig. 12. (a) Total energy used and waste heat in integrated steel plants [133];

(b) Typical temperatures and flow rates of waste heat sources in integrated steel plant [134].

\section{Benefits and Challenges of WHR}

Waste heat recovery provides an attractive opportunity for getting energy from waste heat, which is usually lost to the environment without any useful work. The basic idea behind waste heat recovery is to try to recover maximum amounts of heat in the plant and to reuse it as much as possible, instead of just flaring it into the surrounding atmosphere. There is a great scope to recover waste heat from various industries by installing waste heat recovery technologies. Although various technologies are commercially available for waste heat recovery, the practical recovery of waste heat is still low and it needs extensive research and development. The waste heat management system is based on the new principal of Reduce, Recycle, and Recovery (RRR) [135, 136]. The process starts with minimizing the waste heat by upgrading the process equipment and increasing the system efficiency. The released heat can be internally recycled and reused in different purposes such as preheating furnaces and materials. Such recycling process of waste heat is considered the most efficient method due to the lower investment cost and higher energy efficiency. The last step is the recovery of extra heat and its utilization either in steam production to achieve some mechanical work or power generation to produce electricity. 
Ways of recovery and reusing heat locally are varied from site to site. The recovered heat can be used in preheating of combustion air or feed water in industrial boilers and consequently reduce the energy consumption. Alternately, the heat exchanger could be used to transfer heat from combustion exhaust gases to hot air which can be used for drying oven or wet materials and subsequently reduce the energy consumption. Based on this concept, many benefits could be achieved form efficient recovery and utilization of waste heat. The benefits include a reduction in an operating cost, production cost, fossil energy consumption, and waste emissions. On the other hand, the main barriers for the implementation of waste heat recovery are represented mainly in long payback periods, lack of viable end users, material constraints (e.g., corrosive or condensable materials in the stream), and specific constraints (product control, inaccessibility and limited space) $[137,138]$. Other barriers are related to the handling process of high-temperature gas streams; for instance, loss of sensible heat due to the installation of scrubber for cleaning of exhaust gas to meet the environmental regulation without connection to heat recovery unit. Many factors are controlling the feasibility of waste heat recovery from which heat quantity/quality, the chemical composition of hot streams, economy scale, accessibility, and transportability $[139,140]$.

The recent analysis was conducted on the role of technology innovation in the enhancement of energy efficiency and reduction of $\mathrm{CO}_{2}$ emissions in [141]. There are a number of Best Available Technologies (BATs) which can be applied in many plants at different production units and enable a significant reduction in energy and $\mathrm{CO}_{2}$ emissions. BATs have demonstrated different relevance of energy saving, as shown in Fig. 13.

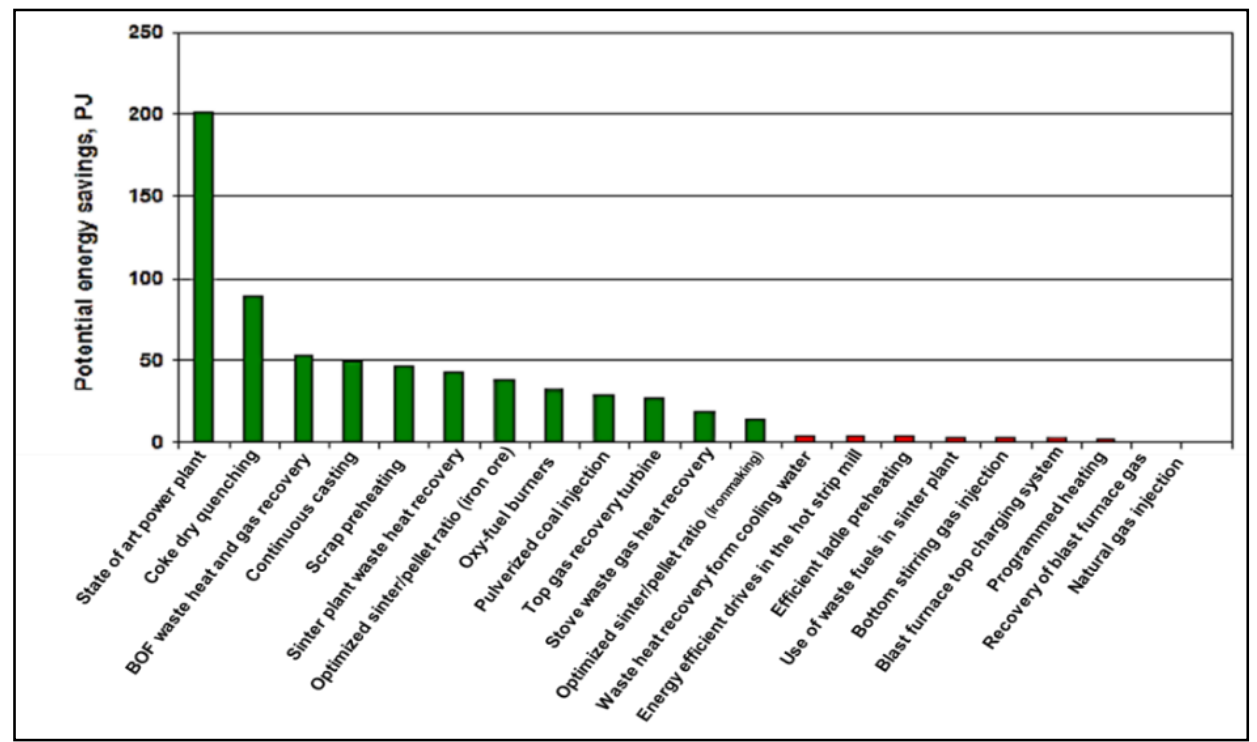

Fig. 13. Potentials of energy saving using BATs in the iron and steel industry [141].

The potential of energy saving at each unit will be achieved if BATs are applied at possible sites. State-of-art power plant exhibited the highest potential for energy saving, which could reach to $200 \mathrm{PJ}$. This can be attributed to the relatively low efficiency of the currently applied heat conversion technologies at many sites. The average efficiency of 
power generation from steam is about $32 \%$, which is below the best practice and it could be improved by the installation of efficient steam boiler and turbine technologies. Coke dry quenching $(\mathrm{CDQ})$ represents the second highest potential with energy saving around 85 PJ. In many cases, the hot coke at $1100{ }^{\circ} \mathrm{C}$ is cooled down by wet quenching which results in loss of sensible heat. The dry quenching using an inert gas such as nitrogen enables the recovery of sensible heat which can be used for the production of highpressure steam or electricity. Other potentials of energy saving could be achieved through efficient recovery and utilization of BOF gas, installation of continuous casting instead of ingot casting, pre-heating of scrap before charging to EAF gas using hot off-gas, sensible heat recovery from hot sinter and optimization of sinter/pellet ratio to reach $50 / 50$.

In BF the energy recovery is possible through heat recovery from hot stoves, application of top gas pressure recovery turbine (TRT) and heat recovery from slag. Heat recovery from $\mathrm{BF}$ stoves can be achieved through the implementation of recuperative, steam production by a heat pump or drying of pulverized coal. Many of BFs are not operate at high pressure, which makes the heat recovery from top gas somewhat difficult and uneconomical. The gases leaving the top of the furnace are approximately $0.25-2.5$ bar and have a temperature of around $200^{\circ} \mathrm{C}$. This pressure and temperature are comparatively quite low and make the investment in heat recovery quite difficult. Top gas pressure recovery is suitable only for large modern BFs and high-temperature gases. On the other hand, waste heat recovery from BF slag represents the next frontier to enhance energy efficiency and reduce emissions in the steel industry.

\section{WHR from BF Slag}

The global annual generation of BF slag is approximately $400 \mathrm{Mt}$. Slag is tapped at $1450-1500{ }^{\circ} \mathrm{C}$ with heat content $\sim 1.6-1.8 \mathrm{GJ} /$ ton slag. Other slags come from steelmaking BOF and EAF as can be seen in Table 3 [142].

Table 3. Types and characteristics of slags [142].

\begin{tabular}{lccccc}
\hline Process & $\begin{array}{c}\text { Average } \\
\text { temperature, } \\
{ }^{\circ} \mathrm{C}\end{array}$ & $\begin{array}{c}\text { Average } \\
\text { slag rate, } \\
\mathrm{kg} / \mathrm{tls}\end{array}$ & $\begin{array}{c}\text { Estimated } \\
\text { slag } \\
\text { production } \\
\text { in 2008, Mt }\end{array}$ & $\begin{array}{c}\text { Slag } \\
\text { enthalpy } \\
\text { GJ/t }\end{array}$ & $\begin{array}{c}\text { Heat } \\
\text { value, } \\
\text { TWh/a }\end{array}$ \\
\hline $\begin{array}{l}\text { Hot metal } \\
(\mathrm{BF})\end{array}$ & 1450 & 275 & 236 & 1.6 & 105 \\
$\begin{array}{l}\text { Steel } \\
(\mathrm{BOF})\end{array}$ & 1300 & 126 & 112 & 1.3 & 40 \\
$\begin{array}{l}\text { Steel } \\
(\text { EAF })\end{array}$ & 1550 & 169 & 69 & 1.8 & 35 \\
\hline
\end{tabular}

The waste heat recovery from slags could play a vital role in achieving the goals of energy saving and the reduction of $\mathrm{CO}_{2}$ emission in the iron and steel industry. Slag has a wide range of applications as it can be used in Portland cement, ceramics, concrete, asphalt, roadbed materials, and construction aggregate. The efficiency of slag in these different applications is mainly based on its cooling conditions and applied the cooling process. Currently, wet granulation by water is the most common method used for quick cooling of slag to produce a glassy product, namely ground granulated BF slag (GGBFS), 
which is used to improve slag cement quality. In the wet granulation method, 1.0-1.2 ton of water is required to granulate 1.0 ton of slag. The rapid cooling of molten slag in water prevents the crystallization process of slag and breaks the slag into small particles. The glassy phase in ground granulated BF slag can reach $95 \%$ using wet granulation method. Although the wet granulation works properly for glassy slag production, it seems inefficient from economic and environmental aspects. Most of the sensible heat of slag is lost and a large quantity of low-temperature steam generates which can be only used as heat supply during the winter time in some countries. It causes environmental pollution from the generated $\mathrm{SO}_{2}$ and $\mathrm{H}_{2} \mathrm{~S}$, also energy lost in the drying process of wet slag. Up to now, there is no technology applied on an industrial scale to recover and utilize the waste heat of molten slag all over the world. Dry cooling with energy recovery is recently supposed to granulate slag and recover the waste heat [143]. Fig. 14 illustrates a schematic diagram of the traditional wet and innovative dry granulation of slag [143, 144]. The granulated slag by fast dry cooling does not need any further drying, which could cut $30 \mathrm{~kg} \mathrm{CO} / \mathrm{t}$ slag and reduce the annual $\mathrm{CO}_{2}$ emission by $6.3 \mathrm{Mt} / \mathrm{a}$ compared to wet granulation [143]. There is a wide range of dry granulation and heat recovery techniques which can be classified into physical and chemical methods.

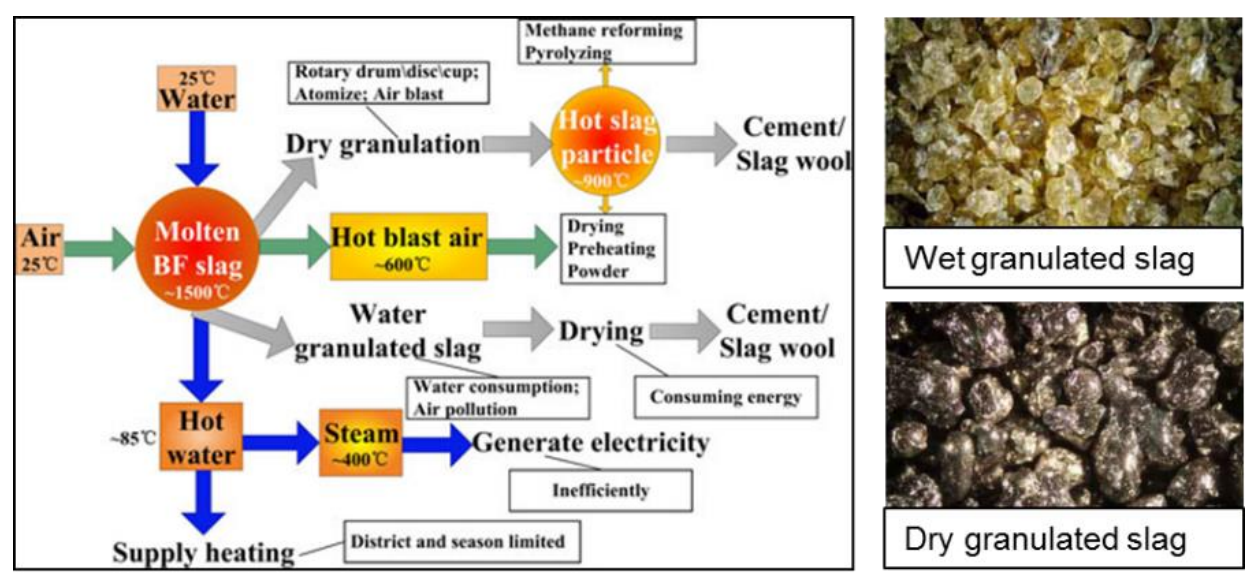

Fig. 14. The schematic diagram for wet and dry granulation of blast furnace slag [143, 144].

In WHR from BF slag using physical methods, a high-speed rotating cup (RCA or RMCA) is used for the granulation as shown in Fig. 15 [143, 144]. High-temperature liquid slag is directly poured into the high-speed rotating cup which enforced the slag to eject radially under the influence of centrifugal force. The hot granules (1-6 mm) bounce off the vessel walls and fall into the bed. The diameter and speed of the rotating cup have to be optimized to reach an adequate level of slag granulation. The bed kept in motion by injecting cooled air down the bed. Heat exchange takes place between the hot granules and cooled air. The hot air is collecting at the top of the vessel and passes to a waste heat recovery system to produce superheated steam. It was estimated that $120 \mathrm{t} \mathrm{slag} / \mathrm{h}$ could generate 29 ton of steam for a steam turbine connected to a generator to produce about 6.5 MWel [143]. In a successful commercial trial, about $59 \%$ of heat is recovered by RCA and slag particles were cooled down to $250{ }^{\circ} \mathrm{C}$ [144]. 


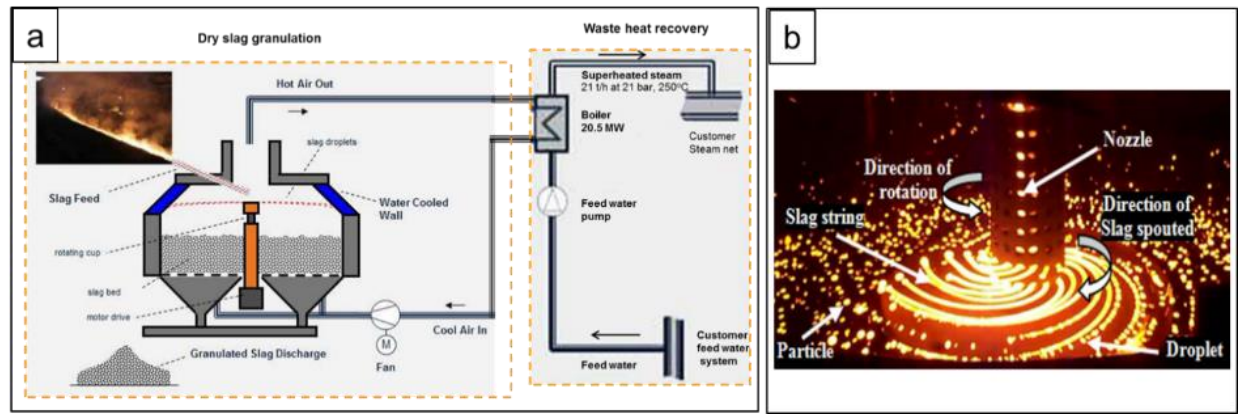

Fig. 15. (a) Rotary cylinder atomizer (RCA) with heat recovery [143], b) Rotary multi-nozzle cup atomizer (RMCA) [144].

Various techniques were applied for dry granulation of slag based on the mechanical crushing method $[145,146]$. Some of these techniques (e.g., solid slag impingement, mechanical stirring) are commercialized for a short term and it could not continue due to the low quality of granulated slag, for instance, non-uniform size. In one of the recently developed dry granulation method, as seen in Fig. 16, the liquid slag is poured into the mold and small cold steel spheres are added eventually over the liquid slag surface. The sphere balls penetrate the liquid steel bath and act as a coolant for hot slag. The temperature of the buffer, from slag and steel balls, becomes around $650{ }^{\circ} \mathrm{C}$, which allows efficient heat recovery based on counter-current heat flow between the descending hot buffer and ascending cold air. The outcome hot air at $\sim 600{ }^{\circ} \mathrm{C}$ can be used in pre-heating combustion air or to operate the steam turbine. The ingot consists of steel balls and slag is dropped down on steel plate to disintegrate into granulated slag particles and steel spheres. The glassy phase in the granulated slag is about $95 \%$, which meets the requirements of the cement industry.

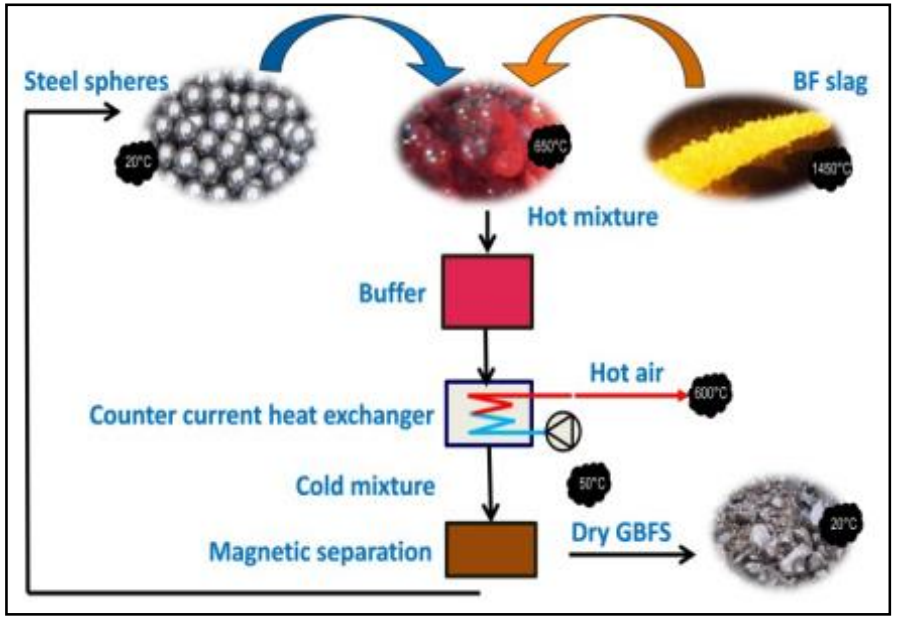

Fig. 16. Paul Wurth dry granulation mixing method [146].

Chemical methods can also be efficiently used in WHR from molten slag as many of chemical reactions are endothermic and required heat to proceed. The sensible waste 
heat of slag can supply the required heat. Reforming of NG by water vapor or carbon dioxide to generate $\mathrm{CO}$ and $\mathrm{H}_{2}$ is an endothermic process. Molten slag can be used for methane reforming $[147,148]$. In this case, the hot slag will not only act as a heat carrier for methane reforming but also as a reaction catalyst. Streams of $\mathrm{CH}_{4}$ and $\mathrm{H}_{2} \mathrm{O} / \mathrm{CO}_{2}$ are applied to cool down the granulated liquid slag and intensive heat exchange takes place. The sensible heat from slag promoted the endothermic reaction of methane reforming and generates $\mathrm{H}_{2}$ and $\mathrm{CO}$, which means that the sensible heat is transformed into chemical heat stored in the product fuel gases. The generated hot gases are cooled down and go to the methanation reactor in which the reversible reaction takes place to give $\mathrm{CH}_{4}$ and $\mathrm{H}_{2} \mathrm{O}$, which can be once more recycled for slag cooling. The sensible heat in molten slag can be exploited in pyrolysis or endothermic gasification reaction of coal/biomass, as shown in Fig. 17(a) [148]. It can be also used in pyrolysis/gasification of municipal solid wastes such as electronic board as shown in Fig. 17(b) [144, 149]. The solid wastes are crushed into small pieces and fed into shaft bed. Rotary multi-nozzle cup atomizer is used for granulation of slag particles. The granulated slag particles at $\sim 900{ }^{\circ} \mathrm{C}$ are fed into shaft containing the crushed waste solid materials. The gasification takes place to develop $\mathrm{CO}$, $\mathrm{H}_{2}$, and $\mathrm{CH}_{4}$.
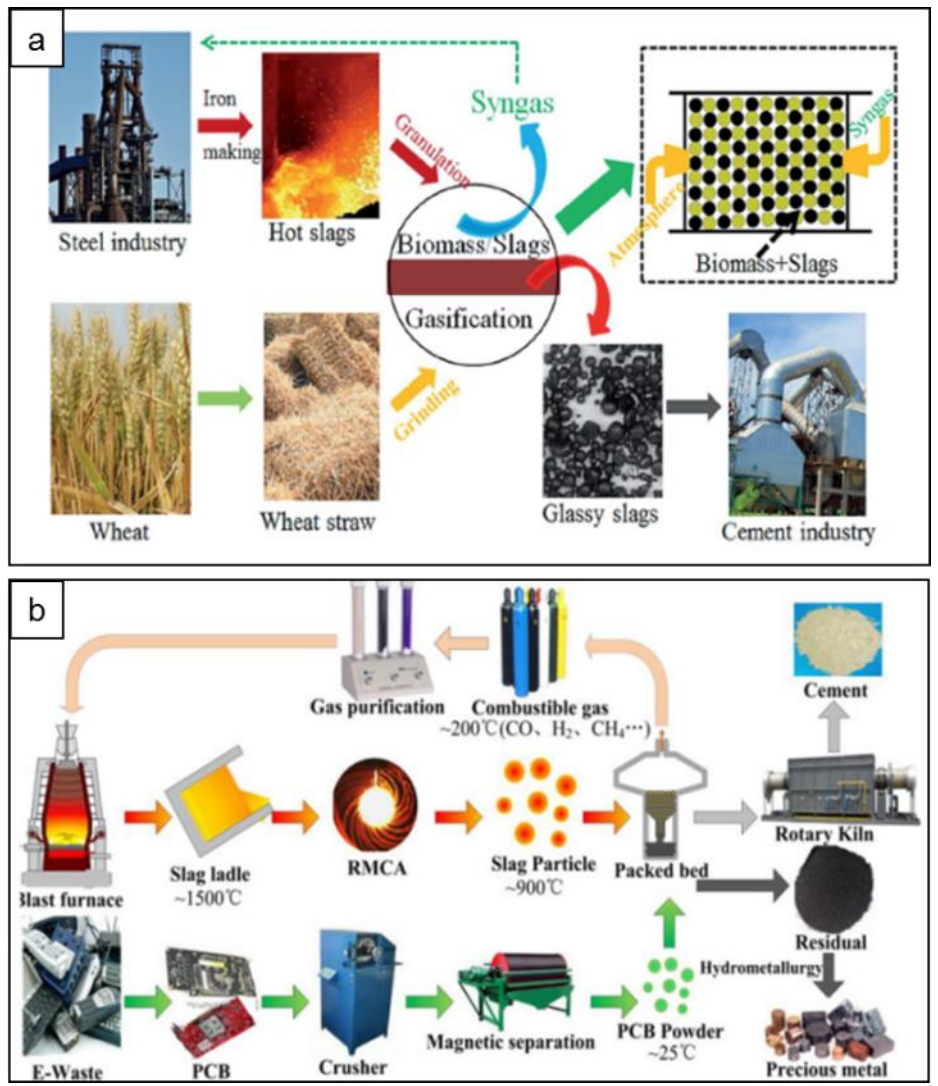

Fig. 17. Utilization of hot slag in (a) Pyrolysis of biomass [148], (b) Pyrolysis of solid waste [144, 149]. 
Table 4 summaries the developed processes for waste heat recovery form BF slag and illustrate the capacity and rate of heat recovery [150].

Table 4. Developed processes for waste heat recovery from slags [150].

\begin{tabular}{|c|c|c|c|c|c|c|c|c|}
\hline & $\begin{array}{l}\text { Developer/ } \\
\text { Process } \\
\text { name }\end{array}$ & $\begin{array}{l}\text { Slag } \\
\text { type } \\
\& \\
\text { temp. }\end{array}$ & $\begin{array}{c}\text { Industrial } \\
\text { test } \\
\text { scale, } t / h\end{array}$ & $\begin{array}{c}\text { Process } \\
\text { function and } \\
\text { characteristics }\end{array}$ & $\begin{array}{l}\text { Recovered } \\
\text { media }\end{array}$ & $\begin{array}{c}\text { Heat } \\
\text { recovery, } \\
\%\end{array}$ & $\begin{array}{c}\text { Exergy } \\
\text { recovery, } \\
\%\end{array}$ & $\begin{array}{c}\text { Slag } \\
\text { product }\end{array}$ \\
\hline 1 & $\begin{array}{c}\text { NKK, } \\
\text { Mitsubishi } \\
\text { heavy } \\
\text { industry }\end{array}$ & $\begin{array}{l}\text { BOF } \\
\text { slag, } \\
1600\end{array}$ & 80 & $\begin{array}{c}\text { Air- } \\
\text { atomization, } \\
\text { heat } \\
\text { exchanger } \\
\text { generates } \\
\text { steam }\end{array}$ & $\begin{array}{l}500^{\circ} \mathrm{C} \text { air } \\
\text { and } 270 \\
\mathrm{kPa} \\
\text { saturated } \\
\text { steam }\end{array}$ & $\begin{array}{c}\text { Hot air: } \\
39.95 \%, \\
\text { steam: } \\
41.4, \\
\text { total } \\
81.35\end{array}$ & 39.9 & $\begin{array}{c}\text { Easy to be } \\
\text { weathering } \\
\text { dusted }\end{array}$ \\
\hline 2 & $\begin{array}{l}\text { Sumitomo } \\
\text { metal }\end{array}$ & $\begin{array}{l}\text { BF } \\
\text { slag, } \\
1400\end{array}$ & 50 & $\begin{array}{c}\text { RCA, FB, } \\
\text { packed bed, } \\
\text { heat exchange }\end{array}$ & $600^{\circ} \mathrm{C}$ air & 55 & 38.9 & $\begin{array}{c}\text { Fine } \\
\text { aggregate } \\
\text { for } \\
\text { concrete }\end{array}$ \\
\hline 3 & MEROTEC & $\begin{array}{l}\text { BF } \\
\text { slag, } \\
1450\end{array}$ & 40 & $\begin{array}{c}\mathrm{FB} \text {, heat } \\
\text { exchanger } \\
\text { recover steam }\end{array}$ & $\begin{array}{c}400 \mathrm{kPa} \\
\text { saturated } \\
\text { steam }\end{array}$ & 65 & 38.8 & Un-known \\
\hline 4 & NKK & $\begin{array}{l}\text { BF } \\
\text { slag, } \\
1400\end{array}$ & N.A & $\begin{array}{l}\text { Drum } \\
\text { quenching, } \\
\text { recovering } \\
\text { heat }\end{array}$ & $\begin{array}{l}250^{\circ} \mathrm{C} \\
\text { high } \\
\text { boiling } \\
\text { point } \\
\text { organic } \\
\text { liquid }\end{array}$ & 40 & 16.3 & $\begin{array}{l}\text { Vitreous } \\
\text { ratio } \\
>95 \%\end{array}$ \\
\hline 5 & NSC & $\begin{array}{l}\text { BF } \\
\text { slag, } \\
1400\end{array}$ & 7 & $\begin{array}{l}\text { Molten slag } \\
\text { poured into } \\
\text { mold, heat } \\
\text { exchange } \\
\text { mold wall }\end{array}$ & Hot water & $60-70$ & $<12$ & $\begin{array}{c}\text { Fine } \\
\text { aggregate } \\
\text { for } \\
\text { concrete }\end{array}$ \\
\hline 6 & NSC & $\begin{array}{l}\text { BF } \\
\text { slag, } \\
1450\end{array}$ & 100 & $\begin{array}{l}\text { Air- } \\
\text { atomization, } \\
\text { first heat } \\
\text { exchange by } \\
\text { the wind } \\
\text { tunnel, } \\
\text { second heat } \\
\text { exchange by } \\
\text { the multi- } \\
\text { fluid bed }\end{array}$ & $\begin{array}{c}510_{\text {st }}^{\circ} \\
\text { air }(1 \\
\text { exchange), } \\
6500 \mathrm{o} \text { air } \\
\text { nd } \\
\text { exchange) }\end{array}$ & $\begin{array}{c}1 \stackrel{\text { st }}{1}: 47.8 \\
2^{\text {nd }}: 14.8 \\
\text { Total } \\
62.6\end{array}$ & 41.5 & $\begin{array}{l}\text { Cement } \\
\text { material }\end{array}$ \\
\hline 7 & $\begin{array}{c}\text { Conventional } \\
\text { water } \\
\text { granulation }\end{array}$ & $\begin{array}{c}\text { BF } \\
\text { slag, } \\
1450\end{array}$ & N.A & $\begin{array}{l}\text { High-pressure } \\
\quad \text { water } \\
\text { granulation, } 5 \\
\text { t water/t slag }\end{array}$ & $\begin{array}{l}80^{\circ} \mathrm{C} \text { hot } \\
\text { water }\end{array}$ & 73 & 9.5 & $\begin{array}{l}\text { Cement } \\
\text { material }\end{array}$ \\
\hline 8 & $\begin{array}{l}\text { CDQ gas- } \\
\text { solid heat } \\
\text { exchange } \\
\text { process }\end{array}$ & $\begin{array}{c}\text { Red } \\
\text { hot } \\
\text { coke, } \\
1000\end{array}$ & N.A. & $\begin{array}{l}\text { Coke packed } \\
\text { heat exchange }\end{array}$ & $\begin{array}{c}800^{\circ} \mathrm{C} \\
\text { nitrogen }\end{array}$ & 80 & 73 & N.A. \\
\hline
\end{tabular}




\section{Summary and Conclusions}

The present article has thoroughly discussed the recent modifications and developments which were recently conducted in the BF technology to reduce energy consumption and $\mathrm{CO}_{2}$ emission and can be summarized in the following points:

(1) The top charging system was developed in large modern BF to assure a proper distribution of feeding materials and gas streaming inside the furnace. Developing new burden distribution system is expected in the future, which will be able to reach an optimum packed structure in the BF maintaining the shaft permeability in low coke rate. The developed measuring systems and devices were able to give a clear vision on the inner status of the BF and describe many of unclear phenomena.

(2) The conventional top charged burden including sinter, pellets and metallurgical coke was reached a high level of quality makes BF works close to the ideal conditions. Successful trails were implemented on charging active nut coke inside the iron ore burden layers which accompanied by lower coke consumption and higher productivity of hot metal. The top charging of in-plant fines in the form of cold bonded briquettes or pre-reduced agglomerates into the BF has provided good solutions to enhance the recirculation of residues, save virgin resources, reduce the landfill materials, and reduce the energy consumption. The partial replacement of conventional agglomerates and fossil fuels with novel top charging biomass-iron ore composites were able to reduce the thermal reserve zone temperature and consequently the coke consumption and fossil $\mathrm{CO}_{2}$ emission. The main challenge is still represented in the relatively low mechanical strength of the novel composites and bio-agglomerates compared to the conventional agglomerates.

(3) The injection of pulverized coal through tuyeres was able to reduce the load on cokemaking, utilize low quality coal resources, and reducing the overall costs; however, further development in PCI technology is still needed to keep the coal replacement ratio for coke high at injection rate higher than $200 \mathrm{~kg} / \mathrm{tHM}$. Injection of pre-treated biomass on account of $\mathrm{PC}$ has significant potential in reducing the fossil $\mathrm{CO}_{2}$ emission from the $\mathrm{BF}$, but technical and economic constraints are still main issues to be addressed in future work.

(4) The generated off-gases in the integrated steel plant can be used more efficient if it is injected into the BF instead of its flaring in the atmosphere. The BF offgas can be recycled after separation of $\mathrm{CO}_{2}$ while coke oven gas and converter gas can be directly injected into the $\mathrm{BF}$ to reduce the fossil fuels and $\mathrm{CO}_{2}$ emission. The waste plastics can be efficiently injected into the $\mathrm{BF}$ as an alternative reducing agent to fossil fuels; however, the collection system and pretreatment methods are still representing the main challenges for its efficient implementation.

(5) The recovery of waste heat represents the next frontier to enhance energy efficiency and reduce emissions in the steel industry. The sensible heat of BF slag can be used in the production of superheated steam for power generation. The sensible heat can be used in the reforming of natural gas or pyrolysis of coal, biomass, and waste plastics. The long payback period of investment cost represents the main challenges for its practical implementation. 


\section{Acknowledgment}

The author acknowledges the support provided for this work from EIT RawMaterials for CIRRUS Project and the support from Vinnova and Energy Agency in Sweden supporting the research projects OsMet (project no. 2017-01327), InnoBind (project no. 2017-05449), and Bioagglomerat (project no. 39150-1). The paper is a contribution from CAMM, Centre of Advanced Mining and Metallurgy, at the Luleå University of Technology. The author wish to thank PRISMA Center at Swerim for the invaluable contributions provided by SSAB Merox, SSAB Special Steel and LKAB.

\section{References}

[1] World Steel Association, "World steel in figures 2018", https://www.worldsteel.org/en/dam/jcr:f9359dff-9546-4d6b-bed0996201185b12/World+Steel+in+Figures+2018.pdf. Accessed 31 December 2018.

[2] World Steel Association, "World crude steel output increases by 5.3\% in 2017" https://www.worldsteel.org/media-centre/press-releases/2018/World-crude-steeloutput-increases-by-5.3--in-2017.html. Accessed 31 December 2018.

[3] R. Haslehner, B. Stelter, N. Osio, "Steel as a Model for a Sustainable Metal Industry in 2050, Industrial Products \& Processes, Sustainability", https://www.bcgperspectives.com/content/articles/metals-mining-sustainabilitysteel-as-model-for-sustainable-metal-industry-2050/. Accessed 09 December 2016.

[4] World Steel Association, "Steel's contribution to a low carbon future and climate resilient societies", https://www.worldsteel.org/publications/position-papers/steel-scontribution-to-a-low-carbon-future.html. Accessed 27 November 2018.

[5] United Nations Framework Convention on Climate Change, http://unfccc.int/paris_agreement/items/9485.php. Accessed 09 December 2016.

[6] V. Shatokha: Journal of Sustainable Development, 5 (2016) 289-300.

[7] European 20-20-20 Targets, RECS International, http://www.recs.org/glossary/european-20-20-20-targets. Accessed 10 December 2016.

[8] American Iron and Steel Institute (AISI), http://www.steel.org/makingsteel/technology/publications/co2-breakthrough-factsheets.aspx. Accessed 10 December 2016.

[9] World Steel Association. Resource efficiency, https://www.worldsteel.org/steel-bytopic/sustainable-steel/environmental/efficient-use.html. Accessed 10 December 2016.

[10] A. Babich , D. Senk, HW Gudenau, KT Mavrommatis: Handbook of Ironmaking. $1^{\text {st }}$ edition, Wissenschaftsverlag Mainz; 2008, II-1-12.

[11] A. Ghosh, A. Chatterjee: Ironmaking and Steelmaking, theory and Practice, 2 ed., PHI Learning Private Limited, New Delhi, 2008, 24-38.

[12] POSCO ignites the largest $\mathrm{BF}$ in the world, http://emetallicus.com/en/news/world/posco-ignites-the-largest-blast-furnace-in-theworld.html. Accessed 20 December 2016.

[13] P. Kowitwarangkul, Mini BF concept for Thailand conditions, M.Sc. Thesis, RWTH Aachen University, 2009.

[14] J.-M. Steiler, E. Hess, In: Proceeding $4^{\text {th }}$ International Congress of Science and Technology of Ironmaking (ICSTI), Osaka, ISIJ, 2006, p.10. 
[15] K. Mülheims, M. Peters and H. B. Lüngen, In: Proceeding $3^{\text {rd }}$ International Conference on Science and Technology of Ironmaking (ICSTI), Dusseldorf, StahlInstitut VDEh,Verlag Stahleisen, 2003, p.1.

[16] M. Peters, H. B. Lüngen: In: Proceeding $3^{\text {rd }}$ International Conference on Science and Technology of Ironmaking (ICSTI), Dusseldorf, Stahl-Institut VDEh,Verlag Stahleisen, 2003, p.33.

[17] S. Seetharaman: Treatise on process metallurgy, Industrial processes, vol. 3, part A, $1^{\text {st }}$ ed., Elsevier Ltd, 2014, p. 1810.

[18] I. Carmichael, C. Thirion, R. Goffin, In: Proceeding of the Iron and Steel Technology Conference (AISTech), Cleveland, Ohio, Association for Iron \& Steel Technology, 2006, p 391.

[19] Clean Coal Technology, BF granular coal injection system, http://infohouse.p2ric.org/ref/16/15866.pdf. Accessed 21 December 2016.

[20] J. Zetterholm, X. Ji, B. Sundelin, P.M. Martin, C. Wang: Energy Procedia, 75 (2015) $1758-1765$.

[21] C. Wang, J. Karlsson, L. Hooey, A. Boden, In: Proceeding World Renewable Energy Congress, Linköping, Linköpping University Electronic Press; Linköpings Universitet, 2011, p. 1537.

[22] J. Rieger, C. Weiss, B. Rummer: Journal of Cleaner Production, 88 (2015) 254-261.

[23] D. Senk, P. Schmöle: Basic master course lecture "Metallurgy and Recycling", RWTH Aachen, IEHK, Ferrous Metallurgy Department, WS 2009/2010.

[24] P. Lacroix, G. Dauwels, P. Dufresne: Revue de Métallurgie, 98 (2001) 259-268.

[25] A. Podkorytov, A. Kuznetsov, E. Dymchenko: Metallurgist, 53 (2009) 322-328.

[26] L. Nikitin, M. Mar'yasov, V. Gorbachev: Metallurgist, 43 (1999), 30-33.

[27] A. Babich, D. Senk, S. Yaroshevskiy, In: Proceeding of $3^{\text {rd }}$ International Conference on Process Development in Iron and Steelmaking (SCANMET III), Lulea, MEFOS, 2008, p. 227.

[28] A. Babich, D. Senk, H.W. Gudenau: Ironmaking and Steelmaking, 36 (2009) 222229.

[29] E.A. Mousa, D. Senk, A. Babich: Steel research international 81 (2010) 706-715.

[30] E.A. Mousa, D. Senk, A. Babich, In: Proceeding $8^{\text {th }}$ Int. European Coke and Ironmaking Congress (ECIC), Düsseldorf, VDEh, 2011.

[31] E.A. Mousa: Reduction of iron ore burden materials mixed with nut coke under simulated BF conditions, PhD Thesis, RWTH Aachen University, Shaker Verlag, Aachen, 2010.

[32] E.A. Mousa, A. Babich, D. Senk: ISIJ Int., 51 (2011) 350-358.

[33] S. Watakabe, K. Takeda, H. Nishimura: ISIJ Int. 46 (2006) 513-522.

[34] S. Yaroshevskii, V. Nozdrachev, A. Chebotarev: Metallurgist, 44 (2000) 598-605.

[35] A. Kasai, Y. Matsui: ISIJ Int., 44 (2004) 2073-2078.

[36] A. Babich, Internet Lecture on Coke Quality for Modern Blast Furnace, http://meveus.iehk.rwth-aachen.de. Accessed 20 September 2010.

[37] Q. Song: Effect of nut coke on the performance of the ironmaking BF, PhD Thesis, Delft University of Technology, 2013. ISBN: 97890-6562-324-9

[38] [38] K. Kundvist, M. Brämming, J. Riesbeck, A. Wedholm: Chemical Engineering Transactions, 45 (2015) 739-744.

[39] R. Robinsson, L. Sundqvist, In: Proceeding METEC Congress 2003, $3^{\text {rd }}$ Int. Conference on Science and Technology of Ironmaking, Düsseldorf, VDEh, 2003, p. 370 . 
[40] L. Sundqvist, K.O. Jonsson, H.O. Lampinen, L.E. Eriksson, In: Proceeding of Committee on Raw Materials- Seminar, Brussels, IISI 1999, p. 44.

[41] $\mathrm{CO}_{2}$ efficiency, https://www.ssab.com/company/sustainability/sustainableoperations/co2-efficiency-at-ssab. Accessed 16 February 2019.

[42] A. Andersson, M. Andersson, E. Mousa, A. Kullerstedt, H. Ahmed, B. Björkman, L.S Sundqvist-Ökvist: Metals, 8 (2018), 1-13.

[43] E. Mousa, H. Ahmed, C. Wang: ISIJ Int., 57 (2017) 1788-1796.

[44] E.A. Mousa. C. Chuan: Technical report MEF16047K, Swerea-MEFOS, Luleå, September 2016.

[45] K. Takeda, T. Anyashiki, T. Sato, T. Yamamoto, S. Watakabe, M. Sato, In: Proceeding METEC InSteel Conf., Dusseldorf, VDEh, 2011.

[46] A. Chatterjee: Sponge Iron Production by Direct Reduction of Iron Oxide, $1^{\text {st }}$ ed., PHI Learning, Private Limited, New Delhi, 2010, 82-176.

[47] H. Ahmed: Minerals 8 (2018) 1-20

[48] T. Ariyama, R. Murai, M. Sato: ISIJ Int. 45 (2005) 1371-1378.

[49] D.V. Kovalev, N.D. Vanukova: Metallurgical and Mining Industry, 4 (2012) 22-25.

[50] Y. Ujisawa, K. Nakano, Y. Matsukura, K. Sunahra, S. Komatsu, T. Yamamoto: ISIJ Int., 45 (2005) 1379-1385.

[51] M. Naito, K. Yamaguchi, Y. Inoue, A. Okamoto, T. Yamaguchi: Nippon Steel Technical Report, No. 94, 2006, p. 103.

[52] A. Kasai, Y. Matsui: ISIJ Int., 44 (2004) 2073-2078.

[53] M. Kawanari, A. Matsumoto, R. Ashida, K. Miura: ISIJ Int., 51 (2011) 1227-1233.

[54] S. Ueda, K. Yanagiya, K. Watanabe, T. Murakami, R. Inoue, T. Ariyama: ISIJ Int., 49 (2009) 1505-1512.

[55] H. Mizoguchi, H. Suzuki, S. Hayashi: ISIJ Int., 51 (2011) 1247-1254.

[56] Y. Tanaka, T. Ueno, K. Okumura, S. Hayashi: ISIJ Int., 51 (2011) 1240-1246.

[57] H. Yokoyama, K. Higuchi, T. Ito, A. Oshio: ISIJ Int., 52 (2012) 2000-2006.

[58] S. Machida, H. Sato, K. Takeda: JEF Technical report, No. 13, May 2009, p.7.

[59] C. Biswas, M.G. Chaudhuri, R. Dey: Ironmaking and Steelmaking, 44 (2017) 762 772.

[60] E. Mousa, M. Lundgren, L.S. Ökvist, L-E. From, A. Robels, S. Hällsten, B. Sundelin, H. Friberg, A. El-Tawil: Journal of Sustainable Metallurgy, Published online 06 June 2019. https://doi.org/10.1007/s40831-019-00229-7. Accessed 11 June 2019.

[61] E.A. Mousa, C. Wang, J. Riesbeck, M. Larsson: Renewable and Sustainable Energy Reviews, 65 (2016) 1247-1266.

[62] A. Babich, D. Senk, M. Fernandez: ISIJ Int., 50 (2010) 81-8.

[63] S. Arnsfeld, A. Babich, D. Senk, In: Proceeding $4^{\text {th }}$ Int. Conf. on Process Development in Iron and Steelmaking (SCANMET IV), 10-13 June 2012, Luleå, MEFOS, Vol. 1, p. 639.

[64] K. Ohno, A. Babich, J. Mitsue, T. Maeda, D. Senk, H.W. Gudenau, M. Shimizu: ISIJ Int., 52 (2012) 1482-1488.

[65] A. Babich, D. Senk: ISIJ Int., 52 (2012) 779-787.

[67] J. Mathieson, H. Rogers, M. Somerville, P. Ridgeway, S. Jahanshahi: In: Proceedings of $6^{\text {th }}$ European coke and ironmaking, Düsseldorf, VDEh, 2011.

[68] H. Suopajärvi, T. Fabritius: Sustainability, 5 (2013) 1188-07.

[69] S. Jahanshahi, A. Deev, N. Haque, L. Lu, J. Mathieson, T. Norgate, P. Ridgeway, H. Rogers, M. Sommerville, H. Zughbi, P. Zulli: Recent progress in R \& D on use sustainable biomass/designer chars for steel production. In: Proceeding of Innovation of Ironmaking Technologies and Future International Collaboration - to Overcome 
Energy \& Resource Restrictions in Accordance with Environments, Tokyo, JSPS, Japan, 2014.

[70] T. Norgate, N. Haque, M. Somerville, S. Jahanshahi: ISIJ Int., 52 (2012) 1472-1481.

[71] G. Fick, O. Mirgaux, P. Neau, F. Patisson: Waste Biomass Valorization, 5 (2014) 43 55.

[72] W. Wei, P. Mellin, W. Yang, C. Wang, A. Hultgren, H. Salman: "Utilization of biomass for blast furnace in Sweden - Report I: Biomass availability and upgrading technologies". https://www.diva-portal.org/smash/get/diva2:681739/FULLTEXT 01.pdf. Accessed 11 February 2015.

[73] T. Norgate, D. Langberg: ISIJ Int., 49 (2009) 587-95.

[74] F. Hanrot, D. Sert, J. Delinchant, R. Pietruck, T. Bürgler, A. Babich, M. Fernández, R. Alvarez, M.A. Diez: In: Proceeding of $1^{\text {st }}$ Spanish National Conference on Advances in Materials Recycling and Eco-Energy, Madrid, 2009.

[75] F. Hanrot, D. Sert, A. Babich, R. Pitruck, M. Fernandez, M.A. Diez, T. Bürgler, J. Delinchant-Lété: Contract no. RFSR-CT- 2005-00001, 2008.

[76] E.A. Mousa, A. Babich, D. Senk In: Proceeding METEC \& $2^{\text {nd }}$ ESTAD, Düsseldorf, VDEh, 2015.

[77] S. Ueda, K. Yanagiya, K. Watanabe, T. Murakami, R. Inoue, T. Ariyama: ISIJ Int., 49 (2009) 1505-1512.

[78] H. Mizoguchi, H. Suzuki, S. Hayashi: ISIJ Int., 51 (2011) 1247-54.

[79] H.M. Ahmed, N. Viswanathan, B. Bjorkman: Steel Research Int., 85 (2014) 293-306.

[80] P. Kowitwarangkul, A. Babich, D. Senk: Steel Research Int., 85 (2014) 1501-1509.

[81] P. Kowitwarangkul, A. Babich, D. Senk: In: Proceeding of the Iron and Steel Techology Conference and Exposition (AISTech), Indiana, Association for Iron \& Steel Technology 2014.

[82] Y. Ueki, R. Yoshiie, I. Naruse, K. Ohno, T. Maeda, K. Nishioka, M. Shimizu: Fuel, 104 (2013) 58-61.

[83] V. Strezov: Renewable Energy, 31 (2006) 1892-1905.

[84] P. Bennett, T. Fukushima: In: Proceedings $12^{\text {th }}$ International Conference on Coal Science (ICCS), Cairns, Queensland, Carins Qld, 2003.

[85] S.K. Sarna: http://ispatguru.com/pulverized-coal-injection-in-a-blast-furnace. Accessed 29 February 2016.

[86] L. Juniper L, G. Schumacher: Advances in pulverized fuel technology: understanding coal comminution, combustion and ash deposition. The Coal Handbook: Towards Cleaner Production, Woodhead Publishing Limited, 2013, 312-352.

[87] K. Ishii: Advanced Pulverized Coal Injection Technology and BF Operation, $1^{\text {st }}$ ed, Elsevier Science, Oxford, UK, Pergamon, 2000, 63-82.

[88] T. Kamijou, M. Shimizu: PC combustion in BF. In: Ishii K, editor. Advanced pulverized coal injection technology and BF operation. Netherlands: Pergamon; 2000. pp. 63-82.

[89] M. Greedes, H. Toxopeus, C. van der Vliet: Modern BF Ironmaking-an introduction, $2^{\text {nd }}$ ed., IOS Press BV, Netherland, 2009, 93-114.

[90] J.G. Mathieson, J.S. Truelove, H. Rogers: Fuel 84 (2005) 1229-1237.

[91] R. Schott: Iron and Steel Technology, 10 (2013) 63-75.

[92] E. Raask: Mineral Impurities in Coal Combustion: Behavior, Problems, and Remedial Measures, Textbook, CRC Press, 1985, 484p.

[93] L. Lu, V. Sahajwalla, D. Harris: Energy Fuels, 14 (2000) 869-876.

[94] E. Worrel, P. Blinde, M. Neelis, E. Blomen, E. Masanet: "Energy efficiency improvement and cost saving opportunities for the U.S. iron and steel industry", 
LBNL-Report, United States Environmental Protection Agency. http://www.energystar.gov/ia/business/industry/Iron_Steel_Guide.pdf?25eb-abc5. Accessed 05 February 2016.

[95] O. Lingiardi, O. Burrai, C. Partemio, F. Giandoménico, P. Etchevarne, J.M. Gonzalez, In: Proceeding $1^{\text {st }}$ Inter. Meeting on Ironmaking, Belo Horizonte / MBBrazil, 2001

[96] M. Jampani, P.C. Pistorius, In: Proceedings of the Iron \& Steel Technology Conference (AISTech), Indianapolis, Indiana, Association for Iron \& Steel Technology, 2014.

[97] K.S. Abdel Halim: Materials Letters 61 (2007) 3281-3286.

[98] K.S. Abdel Halim, V.N. Andronov, M.I. Nasr: Ironmaking and Steelmaking 36 (2009) 12-18

[99] G. Wingrowe, D. Satchell, B. Keeman, C. Aswegen. In: Proceeding of Gasification Technologies Conference, San Francisco, California, 1999.

[100] ULCOS Process. http://www.ulcos.org/en/about ulcos/home.php. Accessed 25 December 2016.

[101] J.P. Birat, In: Proceeding $1^{\text {st }}$ Int. Conf. on Energy Efficiency and $\mathrm{CO}_{2}$ Reduction in the Steel Industry, Düsseldorf, VDEh, 2011.

[102] G. Danloy, J. Stel, P. Schmöle. In: Proceedings of the $4^{\text {th }}$ ULCOS Seminar, 1-2 October 2008, SP10-Top Gas Recycling BF. http://www.ulcos.org/en/docs/ seminars/Ref11\%20- \%20SP10_Danloy1 Essen_New.pdf. Accessed 03 June 2011.

[103] Van der Stel. In: Proceeding Scrap Substitutes and Alternative Ironmaking V, Baltimore, USA, 2008.

[104] Z. Guangqing, A. Hirsch: La Revue de Metallurgie, CIT, September $2009387-$ 392.

[105] P. Diemer, H.J. Killich, K. Knop, H.B. Lüngen, M. Reinke, P. Schmöle. In: Proceedings of the $2^{\text {nd }}$ International Meeting on Ironmaking/1st International Symposium on Iron Ore, Vitoria, Brazil, 2004.

[106] P. Diemer, K. Knop, H.B. Lüngen, M. Reinke, C. Wuppermann: Stahl und Eisen 127 (2007) 19-24.

[107] N. Spirin, V. Shvidkiy, Y. Yaroshenko, Y. Gordon. In: Proceeding of METEC \& ESTAD, Düsseldorf, VDEh, 2015.

[108] Z. Yang, Y. Zhang, X. Wang, Y. Zhang, X. Lu, W. Ding: Energy \& Fuels, 24 (2010) 785-788.

[109] I.G. Tovarovskii, A.E. Merkulov: Steel in Translation, 41 (2011) 499-510.

[110] E. Proface, S. Pivot: In: Proceeding METEC InSteelCon 2011, Düsseldorf, VDEh, 2011.

[111] S. Matsuzaki, K. Higuchi, A. Shinotake, K. Saito. In: Proceeding International Congress on the Science and Technology of Ironmaking (ICSTI) Brazilian Metallurgical, Rio de Janeiro, Materials and Mining Association (ABM), 2012.

[112] M. Miwa, H. Okuda, M. Osame, S. Watakabe, K. Saito. In: Procedding METEC InSteelCon 2011, Proc $1^{\text {st }}$ International Conference on Energy Efficiency and $\mathrm{CO}_{2}$ Reduction in the Steel Industry, Düsseldorf, VDEh, 2011.

[113] E.A. Mousa, A. Babich, D. Senk: ISIJ Int. 53 (2013) 1372-1380.

[114] E.A. Mousa, A. Babich, D. Senk: Steel Research International 84 (2013)10851097.

[115] E.A. Mousa, A. Babich, D. Senk. In: Proceeding $1^{\text {st }}$ ESTAD \& $31^{\text {st }}$ JSI Steel Industry Conference, Paris, JSI, 2014. 
[116] E.A. Mousa, A. Babich, D. Senk: Metallurgical and Materials Transaction B, 45B (2014) 617-628.

[117] P. Hellberg, T.L.I. Jonsson, P.G. Jönsson: Scandinavian Journal of Metallurgy 34 (2005) 269-275.

[118] P. Hellberg, T.L.I. Jonsson, P.G. Jönsson, D.Y. Sheng. In: Proceeding $4^{\text {th }}$ International Conference on CFD in the Oil and Gas, Metallurgical \& Process Industries SINTEF / NTNU Trondheim, 2005.

[119] H. Nogami, Y. Kashiwaya, D. Yamada: ISIJ Int. 52 (2012) 1523-1527.

[120] P.E. Kovalenko, A.P. Chebotarev, V.F. Pashinskii, V.M. Zamuruev, I.G. Tovarovskii, N.G. Boiko, P.V. Plevako, B.S. Trunov: Metallurgist 33 (1989) 169170.

[121] T.H. Bürgler, G. Braunnbauer, A. Ferstl: Stahl und Eisen, 124 (2004) 39-42.

[122] United State Environmental Protection Agency: "Available and emerging technologies for reducing greenhouse gas emissions from the iron and steel industry". http://www.epa.gov/sites/production/files/2015-12/documents/ironsteel.pdf. Accessed 24 February 2016.

[123] M. Asanuma, K. Terada, T. Inoguchi, N. Takashima: JFE Technical Report, 2014, p. 110.

[124] The Industrial Efficiency Technology Database, BF system. http://ietd.iipnetwork.org/content/plastic-waste-injection. Accessed 09 February 2016.

[125] A.M. Carpenter: Injection of coal and waste plastics in BFs. IEA Clean Coal Centre, March 2010.

[126] E. Taibi, D. Gielen, M. Bazillian: Renewable and Sustainable Energy Reviews, 16 (2012) 735-44.

[127] S. Ladanai, J. Vinterbäck: Global potential of sustainable biomass for energy. Department of Energy and Technology, Report 13, 2009, Swedish University of Agriculture Sciences, Uppsala, Sweden.

[128] C. Wang, M. Larsson, J. Lövgren, L. Nilsson L, P. Mellin, W. Yang, H. Salman, A. Hultgren: Energy Procedia, 61 (2014) 2184-2187.

[129] C. Wang, P. Mellin, J. Lövgren, W. Yang, H. Salman, A. Hultgren, M. Larsson: Energy Conversion and Management, 102 (2015) 217-226.

[130] J.G. Mathieson, H. Rogers, M.A. Somerville, S. Jahanshahi: ISIJ Int., 52 (2012) 1489-1496.

[131] C. Feliciano-Bruzual, J.A. Mathews: Revista de Metalurgia, 49 (2013) 458-468

[132] H. Suopajärvi, K. Umeki, E. Mousa, A. Hedayati, H. Romar, A. Kemppainen, C. Wang, A. Phounglamcheik, S. Tuomikoski, N. Norberg, A. Andefors, M. Öhman, U. Lassi, T. Fabritius: Use of biomass in integrated steelmaking - Status quo, future needs and comparison to other low- $\mathrm{CO}_{2}$ steel production technologies, Applied Energy 213 (2018) 384-407.

[133] Frost and Sullivan: "Waste heat recovery opportunities in selected US industries", CFrost \& Sullivan 2010. http://www.heatispower.org/wpcontent/uploads/2011/10/Frost-and-Sullivan-on-waste-heat-recovery.pdf. Accessed 23 February 2019.

[134] Z. Xipeng, Z. Shouhang: The prospect of sensible heat recovery of BF slag, The $7^{\text {th }}$ China Iron and Steel annual meeting proceedings, Beijing, 2009.

[135] D. Bellqvist: Report No. MEF12090K, Swerea MEFOS, 2012. 
[136] H. Lu: Capturing the invisible resource: analysis of waste heat potential in Chinese industry and policy options for waste heat to power generation, Lawrence Berkeley National Laboratory, 2015.

[137] Waste heat recovery. http://www.em-ea.org/guide\%20books/book2/2.8\%20waste\%20heat\%20recovery.pdf. Accessed 05 December 2016.

[138] Oak Ridge National Laboratory: "Characterization of the U.S. industrial/commercial boiler population, p. ES4. 2005.

https://www.energy.gov/eere/amo/downloads/characterization-usindustrialcommercial-boiler-population-final-report-may-2005. Accessed 14 June 2019.

[139] Waste Heat Recovery: "Technology and opportunities in U.S. industry prepared by BCS, Incorporated March 2008".

https://www1.eere.energy.gov/manufacturing/intensiveprocesses/pdfs/waste heat $\mathrm{r}$ ecovery.pdf. Accessed 14 December 2016.

[140] C. Wang, D. Bellqvist, L. Nilsson, P. Ivashechkin, V. Reimer, R. Rato, C. Guillon, V. Weber, J.J. Arribas: Energy Procedia, 61 (2014) 2188-2191.

[141] N. Pardo, J.A. Moya: , 54 (2013) 113-128.

[142] M. Barati, S. Esfahani, T.A. Utigard: Energy 36 (2011) 5440-5449.

[143] A. Werner, I. Mcdonald, A. Fleischanderl. In: Proceeding $7^{\text {th }}$ European Coke and Ironmaking Congress, Linz, ASMET, 2016.

[144] Y. Qin, X. Lv, C. Bai, G. Qiu, P. Chen: JOM, 64 (2012) 997-1001.

[145] H. Zhang, H. Wang, X. Zhu, Y.J. Qiu, K. Li, R. Chen, Q. Liao: Applied Energy, 11 (2013) 956-966.

[146] H. Kappes, D. Michels. In: Proceeding METEC \& $2^{\text {nd }}$ ESTAD Cof., Düsseldorf, VDEh, 2015.

[147] Y. Sun, Z. Zhang, L. Liu, X. Wang: Energies, 8 (2015) 1917-1935.

[148] Y. Sun, Z. Zhang, S. Seetharaman, L. Liua, X. Wang: RSC Adv., 4 (2014) 62105-62114.

[149] S. Luo, Y. Zhou, C. Yi: International Journal of Hydrogen Energy, 37 (2012)1508-15085.

[150] G. Li, H. Zhang, H. NI, M. Guo: In: Proceeding $3^{\text {rd }}$ International Slag Valorisation Symposium, Leuven, KU Leuven, 2013.

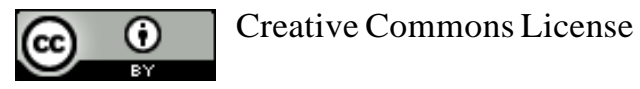

This work is licensed under a Creative Commons Attribution 4.0 International License. 